\title{
KILKA UWAG O KOLORYSTYCE BAZYLIKI NORBERTANEK W STRZELNIE W XIII-XIV WIEKU
}

\author{
A FEW REMARKS ABOUT THE COLOURS \\ OF THE NORBERTINE BASILICA IN STRZELNO IN THE 13TH-14TH C.
}

\begin{abstract}
The article sums up the reflections on the relics of medieval plaster and layers of paint on the walls, columns and pillars of the Norbertine nuns convent in Strzelno completed around the 2nd-3rd quarter of the $13^{\text {th }}$ century. The relics of the polychromies observed by numerous enthusiasts of the Romanesque Strzelno and discovered during archaeological excavations were topped with the results of conservation-restoration works which uncovered the first figural polychromies in the chancel's apse. Following verification of the dating of the colours of the church's interior, an indication was made that in the $13^{\text {th }}$ century, the colour red prevailed; in the $15^{\text {th }}-16^{\text {th }}$ centuries, the figural scenes of the apse sported many colours while the remaining part of the sacrum was brightened up with three-colour, geometric patterns. To complete the range of colours, floor tiles were added. Examples have been provided of specialist painting analyses. The entire arrangement has been compared with selected colourful medieval structures. References have been made to the symbolism of the colours used in the Middle Ages and the contemporary, erroneous perception of Romanesque architecture as rustic, devoid of plaster and colours.
\end{abstract}

Keywords: Strzelno, colours in the medieval Holy Trinity church in Strzelno, status of research, reconstruction of the colours inside the Norbertine nuns convent in the $13^{\text {th }}$ and $15^{\text {th }}-16^{\text {th }}$ centuries, examples of polychrome sacral architecture in Poland, symbolism of colours.

Celem niniejszych rozważań jest pokazanie kolorystyki wnętrza bazyliki Świętej Trójcy w Strzelnie, na Kujawach, w okresie od XIII do XIV wieku oraz prezentacja poglądów dotyczących najstarszych reliktów barwnych tynków i warstw malarskich zachowanych na murach świątyni Norbertanek, wyrażanych na łamach literatury przedmiotu w formie krótkich sugestii lub jednozdaniowych spostrzeżeń, publikowanych głównie w XX wieku. Do tego obrazu dodano obserwacje uzyskane w trakcie prac prowadzonych na strzeleńskim wzgórzu do 2004 roku, zarówno archeologicznych (1981-1986 i 2000-2004), konserwatorskich (2000-2003), jak i remontowo-budowlanych, realizowanych w ramach programu Polonia Romanica (2000-2001). Romańska bazylika Świętej Trójcy - świątynia Norbertanek, tak jak stojąca obok rotunda św. Prokopa w różnych latach i okolicznościach poddawane były badaniom prowadzonym przez historyków sztuki, mediewistów, architektów, zwłaszcza po zakończeniu II wojny światowej. Trwające w ciągu 11 lat badania

* ORCID: 0000-0002-8901-0437, Instytut Archeologii, Uniwersytet Mikołaja Kopernika, Szosa Bydgoska 44/48, 87-100 Toruń, kryssul@umk.pl. 
poprowadzili też archeolodzy (IA UMK: 1981-1986; 2000-2004), dokonując wielu nowych odkryć i weryfikując starsze ustalenia (Chudziakowa 1990; Sulkowska-Tuszyńska 2006, 2010; Karczewski 2001, tam literatura).

Charakterystykę stanu badań i opracowań nad kolorystyką bazyliki Świętej Trójcy w Strzelnie rozpocząć należy od jednego z najważniejszych odkryć dokonanych w klasztorze Panien Norbertanek. Gdy Zdzisław Kępiński w filarach korpusu nawowego bazyliki odkuł cztery romańskie kolumny, w tym dwie wschodnie z wyrzeźbionymi na nich postaciami pod łukami arkadek, napisał, że na całej powierzchni trzonu północno-zachodniej kolumny była „dywanowa” dekoracja z rombów (Kępiński 1946, s. 203). Znacznie później Krystyna Józefowiczówna relacjonowała, że na poddaszu, na skrzyżowaniu transeptu z nawami, „ocalały ślady romańskiej polichromii" (Józefowiczówna 1978, s. 248, przypis 284) ${ }^{1}$. Z krótkich sprawozdań K. Józefowiczówny i Z. Kępińskiego wynika, że „boniowanie na tynku wapiennym, ocalałe $\mathrm{w}$ małych fragmentach, w niektórych fugach między ciosami" zachowało się w rotundzie, na autentycznym romańskim licu nawy, i że takie samo boniowanie przetrwało na murze okrągłej wieży, przy transepcie kościoła Św. Trójcy (Kępiński i Józefowiczówna 1952, s. 375; 1953, s. 229)². Najpewniej z relacji K. Józefowiczówny Zygmunt Świechowski wiedział, że ponad sklepieniem skrzyżowania, w partii łuku tęczowego zachował się „fragment polichromii o barwie żółtej, czerwonej i białej”. Podobna kolorystyka była, według Z. Świechowskiego, „na fragmencie okna fasady zachodniej i w obramieniu jednej z arkad nawy południowej”. Twierdził, że w bazylice Świętej Trójcy zastosowano dwa rodzaje motywów: trójbarwne pasy (czerwono-biało-żółte) ozdabiające wszystkie arkady - wielkie, oddzielające korpus nawowy i prezbiterium od transeptu, i mniejsze międzynawowe ${ }^{3}$, oraz ,boniowanie utworzone przez białe linie rowków rytych w zaprawie, imitujących spoiny”, które zastosowano wewnątrz kościoła (ryc. 1), „na elewacji północnej przy portalu, oraz na murze zewnętrznym okrągłej wieży usytuowanej pomiędzy transeptem północnym a aneksem, u jej podstawy"4,

${ }^{1}$ W cytowanym przypisie Autorka powołała się na informację M. Walickiego (Walicki 1932-33, s. 22).

2 Wcześniej, podczas badań w romańskiej katedrze w Poznaniu (wieża południowa - partia dolna), ci sami odkrywcy opisali zachowaną do wysokości 4,5 m (!) ścianę z kostki granitowej, na której zachował się ,tynk romański, barwiony na czerwono, pokrywający całą powierzchnię kamieni i boniowany zgodnie z rzeczywistym układem kamieni” (Kępiński i Józefowiczówna 1952, s. 371). Stwierdzili, że katedra w Poznaniu, wewnątrz i od zewnątrz była tynkowana. Zewnętrze tynki były zaprawiane czerwono i boniowane, podobnie jak w Strzelnie „na murze zachowanej pod ziemią, okrągłej romańskiej wieży przy kościele Św. Trójcy, rozebranej już w XIII wieku” (Kępiński i Józefowiczówna 1952, s. 375). Uwaga - obie okrągłe wieże flankujące prezbiterium były rozebrane dopiero w XV wieku, przed 1459 rokiem, kiedy rozpoczęto budowę kaplicy Świętej Barbary (Sulkowska-Tuszyńska 2006, s. 116).

3 Takie pasy zrekonstruowano podczas prac remontowych w 2001 roku, po zakończeniu generalnego remontu bazyliki, w ramach programu Polonia Romanica.

${ }^{4}$ Niestety, podczas prac archeologicznych w latach 1981-1986 nie zarejestrowano takich reliktów; prawdopodobnie do tego czasu uległy zniszczeniu. 


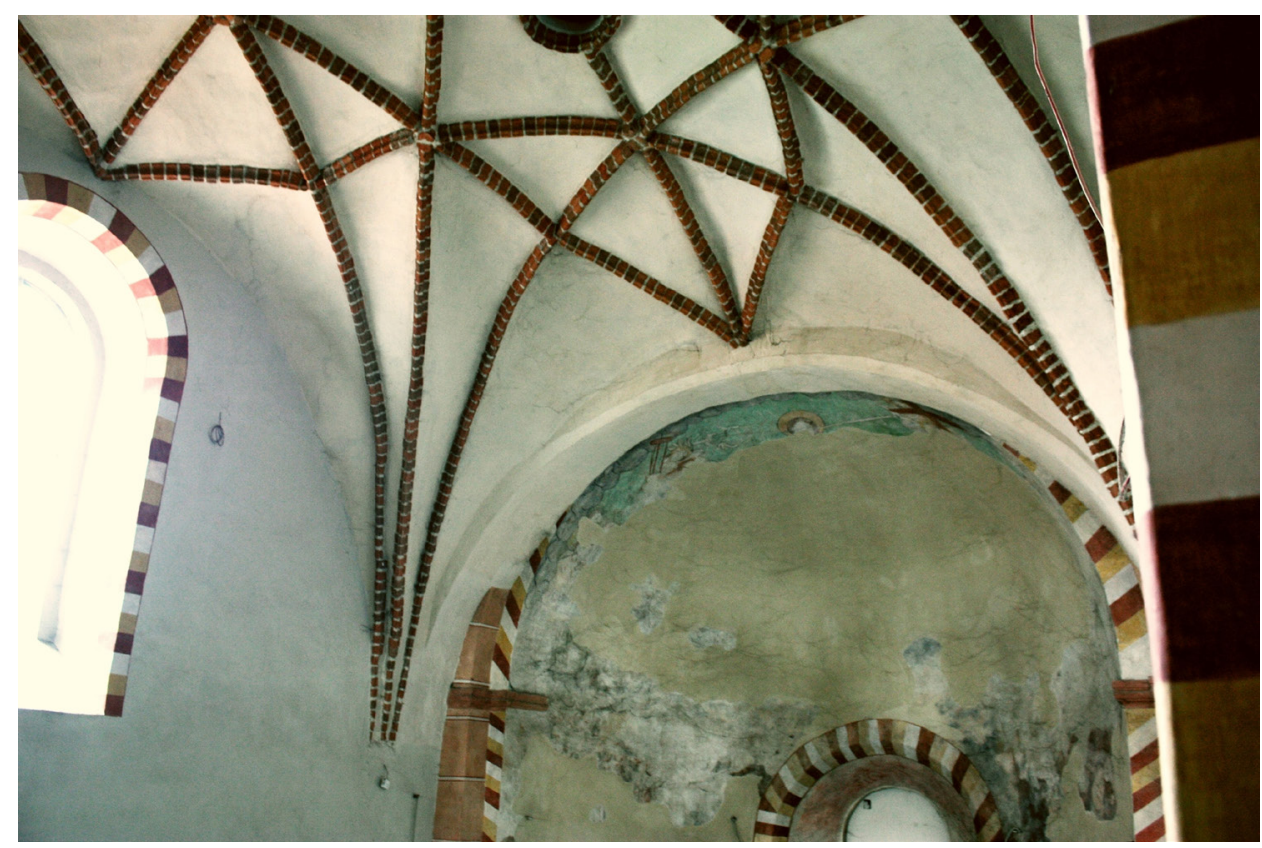

Ryc. 1. Strzelno, bazylika Świętej Trójcy - prezbiterium. Sklepienie i absyda - po bokach i wokół środkowego okna widoczne geometryczne polichromie, w głębi, na konsze absydy relikt figuralnej polichromii. Fot. J. Struwe

o czym wcześniej pisali też K. Józefowiczówna i Z. Kępiński (1952, s. 375; 1953, s. 229; Świechowski 1963, s. 257; 1972, s. 12).

Po zakończeniu I kampanii badań archeologiczno-architektonicznych w Strzelnie (1981-1986), w 1990 roku Jadwiga Chudziakowa relacjonowała odkrycie resztek tynków ze śladami „romańskich polichromii” na osi zachodniej ściany bazyliki, na licu wewnętrznym, pod domniemaną emporą, poniżej poziomu barokowej posadzki, a ponad pierwotnym poziomem użytkowym (Chudziakowa 1990, s. 17, 19, 20 , ryc. 13 , s. $23 ; 1988)^{5}$. Z wniosków istotnych w tym rozważaniu interesuje nas stwierdzenie, że do pierwszego, najstarszego poziomu (+109,6 m n.p.m.), który tworzyła wylewka zaprawy z tłuczniem kamiennym, sięgały tynki kremowe, a polichromie dochodziły do ceramicznej nieszkliwionej i niezdobionej II posadzki (kwadratowe płytki 21 x $4 \mathrm{~cm}$ ). Na podstawie stratyfikacji i ówczesnej datacji brakteatu $^{6}$ odkrytego w warstwie spalonego drewna, pod posadzką II, J. Chudziakowa datowała te polichromie na koniec XIII wieku (Chudziakowa 1990,

\footnotetext{
${ }^{5}$ Ich istnienie stało się przesłanką wzmacniającą tezę o wykluczeniu portalu zachodniego w romańskiej bazylice.

${ }^{6}$ Obecnie takie brakteaty datowane są na XV wiek, patrz niżej.
} 
s. 18-1977). Z kolei Czesław Sikorski twierdził, że nie jest wykluczone, iż „strzeleńska rzeźba architektoniczna była podmalowywana" (Sikorski 1994, s. 40), i odniósł się do opisanych przez Z. Kępińskiego kolorowych rombów (ryc. 2), zachowanych na gładkiej kolumnie, stwierdzając, że ,ślady polichromii uchodzącej dotychczas za pierwotną pokrywają drugą, późniejszą warstwę tynku, która powstała w końcu XIII wieku, po pożarze”. Podobnie datowała te tynki J. Chudziakowa (Sikorski 1994, s. 33; Chudziakowa 1990, s. 20). Wtedy, jak przypuszczała, ściany pokryto polichromią, po której pozostały trójbarwne romby widoczne jedynie na trzonie kolumny południowo-zachodniej. Po badaniach architektonicznych i obserwacji architektury na poziomie poddasza ponad gotyckim sklepieniem, spostrzeżenia J. Chudziakowej i Z. Świechowskiego wykorzystali Bożena Zimnowoda-Krajewska i Jan Salm, dodając własne i stwierdzając ,istnienie dwubarwnej kolorystyki z podłużnych czerwonych klińców, oddzielonych białymi pasami boniowania" na obramieniu łuku absydy prezbiterialnej (Zimonowoda-Krajewska i Salm 1992, s. 28 i 42). Autorzy ci przystali na datowanie oparte na ustaleniach archeologicznych na koniec XIII wieku, ale dla uzyskania pewniejszej chronologii sugerowali zbadanie próbek farb i wyprawy gipsowej (Zimonowoda-Krajewska i Salm 1992, s. 42) . Niestety, takie badania nie zostały wykonane. Po zakończeniu II kampanii archeologiczno-architektonicznej w Strzelnie (2000-2004) w 2006 roku przedstawiono najnowsze wówczas rezultaty odkryć, wykorzystując starsze ustalenia. Odkrycie czerwonożelazistego tynku (ryc. 3) u podstawy filara północno-wschodniego i odprysku wielkiej kolumny międzynawowej z resztkami czerwonożelazistej barwy

\footnotetext{
${ }^{7}$ Niestety, w publikacji w żadnym miejscu nie podano kolorów tych tynków, jedynie „,romańskie polichromie” lub ,polichromie” (Chudziakowa 1990, s. 17, 19, 20). W dokumentacji rysunkowej zachowanej w Instytucie Archeologii UMK zaznaczono dokładnie miejsce i zakres występowania tynków na ścianie zachodniej kościoła, ale opisano je jedynie: „T - tynk z polichromią”. Na kolorowym rysunku widoczne są dwa owalne plastry obwiedzione niebieską kredką (pow. $20 \times 15 \mathrm{~cm}$ ); niebieskim kolorem oznaczano wszelkie tynki i zaprawy. Zatem $\mathrm{z}$ dokumentacji tej nie dowiadujemy się, jakie były kolory tynków na ścianie zachodniej (Strzelno 1983: Dokumentacja rysunkowa nr 200/83 i 201/83; gł. +109,58 do 109,68 m n.p.m.). Tynki te stykały się z II posadzką, o płytkach $21 \times 21 \times$ $4 \mathrm{~cm}$. Patrz też opublikowana dokumentacja biało-czarna w: Chudziakowa 1988:, s. 236, Abb. 12. Natomiast na analogicznej dokumentacji innego wykopu w bazylice (ściana pomiędzy transeptem a nawą płd., vis-à-vis płd.-wsch. filara; gł. 110,04 do 109,85 m n.p.m., powyżej II posadzki $(21 \times 21$ $\times 4 \mathrm{~cm}$ ) i powyżej warstwy brunatnej gliny, zachowane tynki (max. pow. 64 x $15 \mathrm{~cm}$ ) narysowano jako czerwono-pomarańczowe dwie płaszczyzny oddzielone kremowym paskiem $(4-5 \mathrm{~cm}) \mathrm{z}$ dwoma ciemnobordowymi konturami (Strzelno 1983: Dokumentacja rysunkowa nr 182/83). Opisano je następująco: „,na ciosach zachowany fragment tynku o grubości 3-4 mm, pozostałość «dwóch kamieni» o barwie jasnopomarańczowo-czerwonej, obwiedzionych pasem około $1 \mathrm{~cm}$ grubości, w nieco ciemniejszej tonacji; «spoiwo» pomiędzy «kamieniami» - białe, na $3 \mathrm{~cm}$ szerokie" (Strzelno 1983: Dokumentacja rysunkowa nr 183/83 - notatka: Dziennik wykopów 1983 z 20-23.08. 1983, Jerzy Dubikajtis). Jest to więc zdobienie malarskie określane jako boniowanie lub bonie. Patrz też opublikowana dokumentacja biało-czarna w: Chudziakowa 1988, s. 237, Abb. 13.

${ }^{8}$ Gdy po odkuciu ołtarza głównego bazyliki pobrano kilka próbek polichromii, przy okazji zbadano jedną próbkę z filara południowo-wschodniego i stwierdzono, że była to czerwień żelazowa na twardej pobiale. Badania wykonała E. Orłowska (patrz: Sulkowska-Tuszyńska 2006, s. 125).
} 


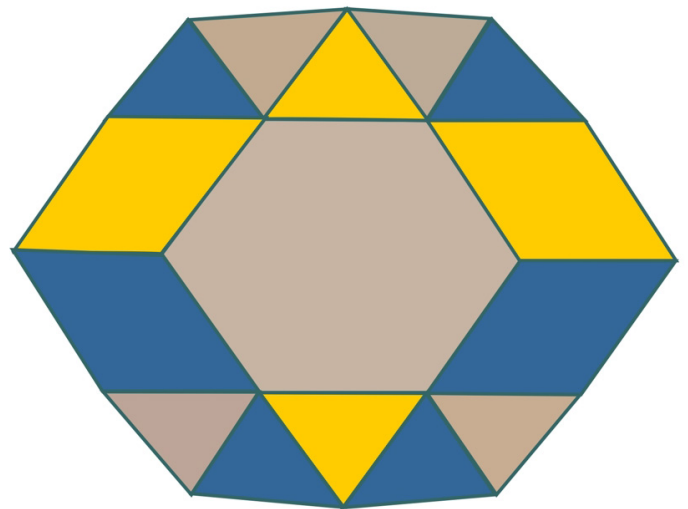

Ryc. 2. Strzelno, bazylika Świętej Trójcy - nawa. Trójbarwne romby pokrywające trzon gładkiej kolumny. Rekonstrukcja na podstawie zachowanego odprysku - K. Sulkowska-Tuszyńska, oprac. graficzne W. Miłek

oraz zaobserwowanie boniowania w skarbcu i na filarze południowo-wschodnim, gdzie na powierzchni ponad $1 \mathrm{~m}^{2}$ zachowały się daty wyryte przez pielgrzymów, w znacznym stopniu przyczyniło się do uzupełnienia skromnego stanu wiedzy o kolorystyce norbertańskiej bazyliki w okresie średniowiecznym. Wówczas stwierdzono, że „chronologia polichromii kościoła konwentualnego w Strzelnie od dawna jest kwestią sporną", że brakuje podstaw do jej zawężenia, podkreślając, że polichromii w postaci boniowania i pasów nie można datować na XIII wiek, że są one młodsze. Udowodniono, że ten typ malarstwa ściennego był praktykowany w Strzelnie jeszcze w 1. połowie XVI wieku i widoczny we wnętrzu bazyliki co najmniej do 3. jego ćwierci (Sulkowska-Tuszyńska 2002; 2006, s. 41, 56-57, ryc. $48-50$, s. 68 , ryc. 70 , s. 121 , przypis 395 , s. $123-125$, ryc. $137-140$, przypis 399, s. 129, przypis 430). Do tego stanu wiedzy dodać należy ważne informacje wynikające z odkrycia tynków i gotyckich malowideł figuralnych, usytuowanych w absydzie prezbiterium oraz geometrycznych, pod wieżami zachodnimi ${ }^{9}$ (Kiepuszewska 2003; Orłowska 2003). Polichromie te, należące już do epoki gotyckiej, nie będą przedmiotem bliższych rozważań w ramach tego artykułu; wzmiankowane są tu dla zrozumienia dalszego toku wykładu.

Dotychczasowe sądy na temat kolorystyki bazyliki strzeleńskiej w średniowieczu dają w rezultacie dalece niespójny i niedokończony obraz, bazujący na niewielkich, mocno zmienionych reliktach. Powłoki obserwowane na kamiennych i ceglanych ścianach bazyliki (poddasze nad sklepieniem) określano jako „romańskie polichromie” lub „kładzione w przestrzeni romańskiej bazyliki”, poza

${ }^{9}$ Odkryte przez konserwatorów w 2003 roku. Pani Tamarze Zajączkowskiej bardzo dziękuję za udostępnienie dokumentacji złożonej w bydgoskiej delegaturze Wojewódzkiego Konserwatora Zabytków w Toruniu. 


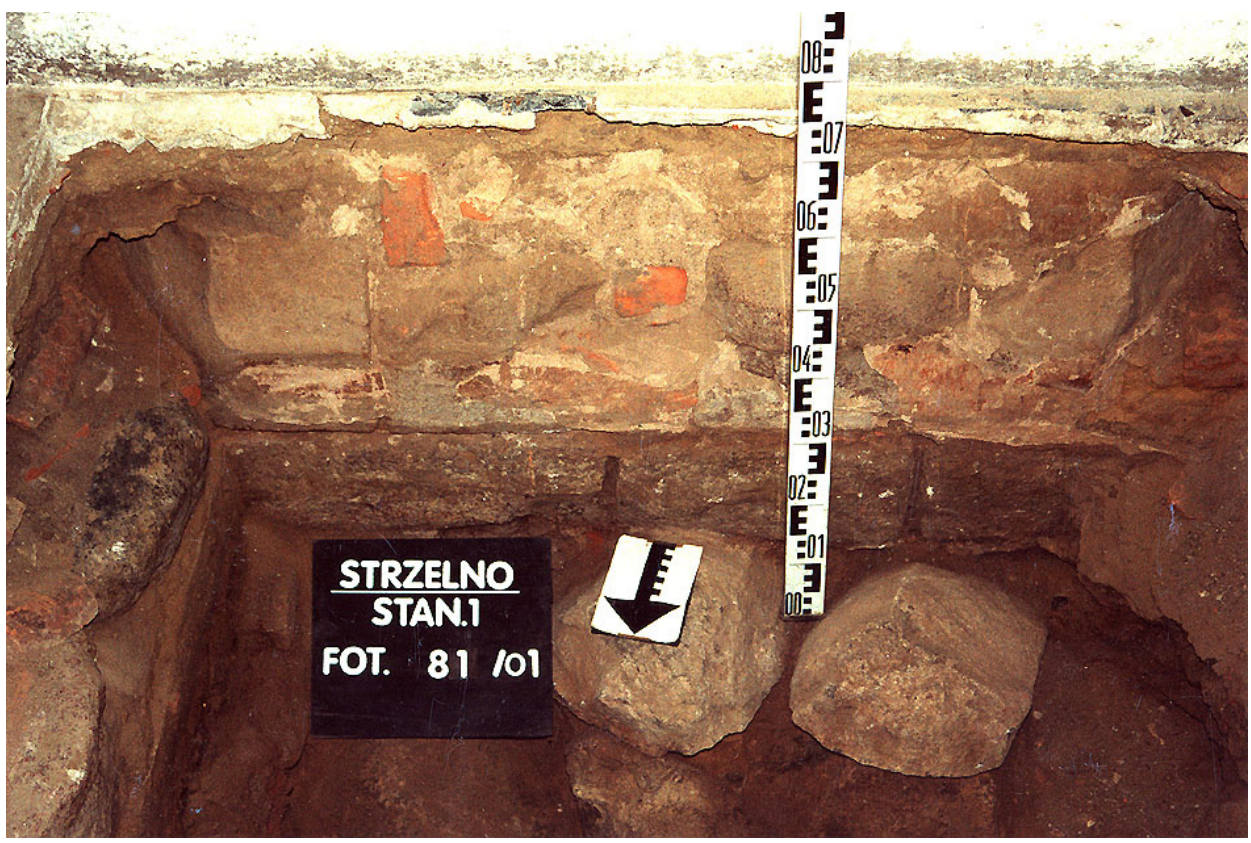

Ryc. 3. Strzelno, bazylika Świętej Trójcy - transept/nawa południowa. Filar północno-wschodni - na kamieniach bazy widoczny kremowy tynk, na nim tynk czerwonożelazisty. Po lewej fundament lektorium, na pierwszym planie ława fundamentowa. Fot. K. Sulkowska-Tuszyńska

wyjątkami, bez podawania podstaw datowania ${ }^{10}$. Podsumujmy zatem, gdzie i co w kościele z kolorystyki okresu średniowiecza. Zebrane z literatury informacje i obserwacje własne pozwalają na wskazanie siedmiu warstw malarskich na powierzchniach kamiennych lub ceglanych - na ścianach, filarach i na rzeźbie figuralnej, w różnych formach i wersjach barwnych, stosowanych pomiędzy XIII a 1. połową XVI wieku (ryc. 4). Są to:

Kremowy twardy tynk, który szczątkowo zachował się na ścianie zachodniej korpusu i na filarach wschodnich, z około 2. połowy XIII wieku (ryc. 3).

Tynk gładzony, kładziony cienką warstwą na licu absydy prezbiterium, o ugrowo-zielonkawym odcieniu - zachowany pod polichromiami figuralnymi, z XIII wieku ${ }^{11}$.

Czerwonożelazisty tynk nałożony na twardy kremowy, zachowany i zaobserwowany na filarach $\mathrm{i}$ ścianach pomiędzy transeptem a nawami bocznymi, oraz

${ }^{10} \mathrm{~W}$ jednym przypadku oparto się na brakteacie, odnosząc ten numizmat do XIII wieku; moneta ta obecnie jest datowana na XV wiek (patrz niżej - problemy z datowaniem).

11 Odsłonięty w 2001 roku podczas remontu bazyliki. Zachowany na dość dużej powierzchni (około $1 \mathrm{~m}^{2}$ ), tuż nad barokową posadzką. Tynki te najpewniej sięgały znacznie głębiej (eksploracja poniżej nie była możliwa); były podobne do tynków bordowożelazistych z około XIII wieku (Sulkowska-Tuszyńska 2002, s. 155, 157, przypis 20, 22). 


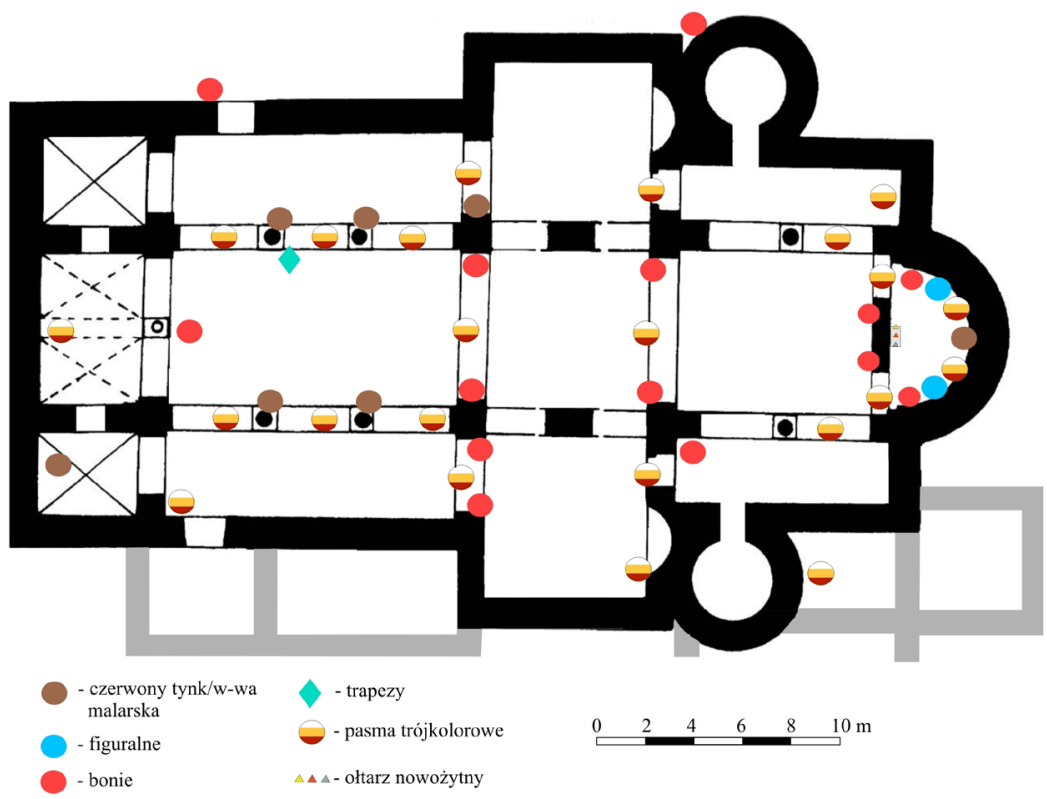

Ryc. 4. Strzelno, bazylika Świętej Trójcy, plan romańskiej bazyliki po gotyckiej przebudowie (wg Chudziakowa 2000 z uzupełnieniami Sulkowska-Tuszyńska 2006) z zaznaczonymi reliktami polichromii średniowiecznych i z nowożytnym ołtarzem głównym. Oprac. K. Sulkowska-Tuszyńska, rys. W. Miłek

bordowożelazista warstwa malarska od około 2. połowy XIII wieku pokrywająca kolumny międzynawowe.

„Dywanowa” dekoracja z rombów (ryc. 2) kremowo-niebiesko-różowych, z czarną (?) konturówką, łączona tylko z kolumną północno-zachodnią, najwcześniej z końca XIII wieku.

Polichromie figuralne, konturowe; wieloelementowa scena na tle malachitowej zieleni widoczna na ścianie absydy prezbiterialnej. Stosunkowo dobrze zachowana na konsze absydy, w większej, środkowej partii całkowicie zniszczona, w dole słabo czytelna, o linearnym opracowaniu formy czarną (?) kreską. Zinterpretowana przez Marię Kiepuszewską ${ }^{12}$ jako wizja Sądu Ostatecznego, z centralnie usytuowaną postacią Chrystusa, datowana na około XV/XVI wiek (ryc. 1) ${ }^{13}$.

12 Maria Kiepuszewska - konserwator dzieł sztuki, odkrywczyni polichromii na konsze absydy (Kiepuszewska 2003, s. 10, 11, 16, 17; Orłowska 2003, s. 4, 6).

$13 \mathrm{Z}$ powodu niemożliwości zrobienia zdjęcia obejmującego całe malowidło (renowacja nastawy ołtarza głównego) na fotografii widoczna jest tylko górna jego część (stan po konserwacji z 2011 roku). 
Geometryczne motywy - trójkolorowe pasy bordowo-biało-żółte, o szerokości około $10-14 \mathrm{~cm}^{14}$, rejestrowane $\mathrm{w}$ wielu miejscach we wnętrzu, głównie na łukach i obramieniach. Regularne prostokąty $(20 \times 30 \mathrm{~cm}$; motyw B) - tzw. bonie, czyli jasnobordowe prostokąty obrysowane ciemnobordową kreską wokół białej „spoiny” o szerokości około $3 \mathrm{~cm}$. Zaobserwowane na filarach wschodnich i w kilku innych miejscach w kościele nad II posadzką (Kiepuszewska 2003, s. 10, 11, 16, 17; Orłowska 2003, s. 4, 6). Oba wątki współistniały ze sobą. Dotychczas określano je jako romańskie i łączono z najstarszym okresem funkcjonowania kościoła, głównie z powodu występowania ponad sklepieniem gotyckim i stykania się z II posadzką, datowaną dotąd na koniec XIII wieku. Obecnie datowane są od lat 50. XV wieku (zbudowanie kaplicy Świętej Barbary przed 12 maja 1459); powtarzane były do XVI wieku' ${ }^{15}$.

Po przeglądzie reliktów tynków i warstw malarskich w obrębie bazyliki podejmijmy próbę rekonstrukcji kolorystyki wnętrza kościoła zbudowanego dla norbertanek w najstarszym okresie jego funkcjonowania do XIV wieku. Wiadomo, że w Strzelnie, we wnętrzu bazyliki używano co najmniej dwóch kolorystycznie różnych piaskowców - żółtoszarego (określany też jako biały lub szary) i różowoszarego (nazywany różowym lub czerwonym). Z szarego piaskowca, sprowadzonego z okolic Konina wykonywano wielkoformatowe elementy, jak trzony kolumn ${ }^{16}$, a niektóre mniejsze, jak głowice i płaskorzeźby, powstawały z piaskowca różowego, przywiezionego aż z Kotliny Kłodzkiej w Sudetach ${ }^{17}$ (Soćko 2008, s. 108; 2009, s. 34, 35). Takie łączenie różnokolorowych skał w jednej bryle mogło być intencjonalne, motywowane względami natury estetycznej, co widać na kolumnie wtórnie wkomponowanej jako podpora sklepienia gotyckiej kaplicy Świętej Barbary (ryc. 5). Tendencja ta mogła mieć też uzasadnienie dla detali niepolichromowanych, eksponowanych pierwotnie na zewnątrz architektury - malowana byłaby skazana na szybką degradację, jak sugerował Adam Soćko (2009, s. 39).

We wnętrzu bazyliki konwentu norbertanek, z najstarszego okresu jej funkcjonowania (głównie w XIII wieku) na unikatowej rzeźbie romańskiej w kilkunastu miejscach zachowały się pozostałości czerwonożelazistej barwy (ryc. 4). Są w szczątkowym stanie zachowania, w postaci małych plamistych zabarwień na

${ }^{14}$ W 2000 roku określony przez konserwatorów - J. Wajdę i M. Markowskiego - jako motyw A.

${ }^{15} \mathrm{Na}$ przykład trójkolorowe pasy bordowo-biało-żółte zastosowano w kościele, potem w kaplicy Świętej Barbary (zbudowana przed 1459) i kilkadziesiąt lat później w skarbcu, budowanym już w XVI wieku!

${ }^{16} \mathrm{O}$ tym, że dekoracja rzeźbiarska kompleksu strzeleńskiego została wykonana z piaskowa sprowadzonego z okolic Konina, pisał już Władysław Łuszczkiewicz w roku 1876. Chodzi o kamieniołom w Brzeźnie, około 60 km od Strzelna (Soćko 2008, s. 108; 2009, s. 34 i przypis 7).

${ }^{17}$ Badania petrograficzne J. Michniewicza (Instytut Geologii UAM 2005- 2007) - rejon Radkowa i Kłodzka. J. Michniewicz stwierdził też, że z tego samego rodzaju skały powstały detale romańskiego portalu ołbińskiego we Wrocławiu (Soćko 2009, s. 35). Proweniencję piaskowca z Sudetów potwierdził geolog W. Bartz, wskazując na rejon Nowa Ruda-Słupiec (Soćko 2009, s. 36). 


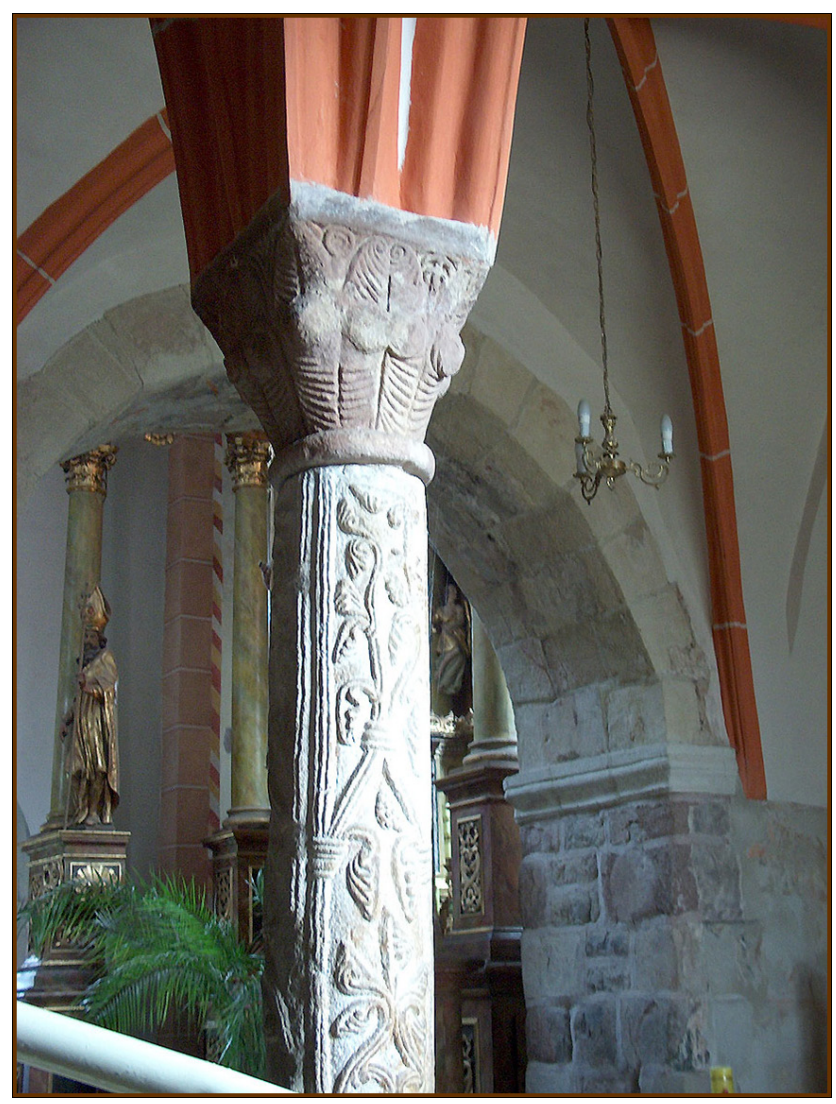

Ryc. 5. Strzelno, bazylika Świętej Trójcy - kaplica Świętej Barbary. Romańska kolumna jako podpora gotyckiego sklepienia. Przykład kolorystycznego kontrastu kamienia - różowa głowica, szary trzon. Fot. K. Sulkowska-Tuszyńska

kamiennych kolumnach ${ }^{18}$ i, co ważne, na czterech potężnych filarach ujmujących obie pary kolumn od wschodu i od zachodu ${ }^{19}$. Z całą pewnością filary wymurowane z ciosów o różnej barwie, wielkości i fakturze powierzchni, dźwigające strop bazyliki wykonany z belek, pokryto kremowym tynkiem, na który położono drugi, czerwonożelazisty, sięgający przypuszczalnie aż do belkowego stropu (ryc. 3). Obserwując ślady polichromii zachowane na kolumnach w korpusie nawowym,

18 Ścianki boczne głowic, tła figur pod arkadami, poziome pasy oddzielające strefy arkadowe.

${ }^{19}$ Czerwona barwa na kolumnach figuralnych była położona bezpośrednio na kamień, a na filarach czerwonożelazisty tynk położono na cienkiej warstwie białego „ciepłego” tynku (zachowana długość plamy z tynkiem do $60 \mathrm{~cm}$, na całej szerokości bazy filara). Odkrycia dokonano podczas badań archeologicznych w 2001 roku (Sulkowska-Tuszyńska 2006, s. 57, ryc. 48, 49 i ryc. 45 - wkładka). Zachowały się na styku z pierwotnym poziomem użytkowym. 
w miejscach mniej narażonych na ścieranie (załamania, szczeliny), można wskazać, że obie kolumny wschodnie (północna z personifikacjami przywar, południowa z personifikacjami cnót) miały abakus i bazę wykonaną z piaskowca o naturalnym, szarym kolorze. Głowice, prawdopodobnie wałki pod głowicami i całe płaskorzeźbione trzony wraz z poziomymi pasami roślinnymi oddzielającymi strefy z arkadkami, były czerwonożelaziste (ryc. 6-8). Poza śladami zachowanymi in situ, na kolumnach, ten wniosek poświadcza też duży odprysk trzonu (około $0,8 \mathrm{~m}$ ) pasujący do ubytku w dolnej strefie kolumny północno-wschodniej, z dobrze widocznymi plamami żelazowej czerwieni (ryc. $8{ }^{20}$. Zatem taka czerwień, miejscami może z odcieniami ceglastoczerwonymi lub żółtymi, pokrywała obie kolumny wschodnie; abakusy i bazy pozostawały w naturalnym kolorze piaskowca ${ }^{21}$. Kolumna południowo-zachodnia, o skręconym trzonie, też miała abakus i bazę szarą; jej głowica była czerwona, może z żółtymi narożami? Wałek poniżej głowicy mógł być pomalowany w skośne paski - żółte i czerwone, podobnie jak trzon - pasma wąskie, dwudzielne, mogły pozostać w naturalnym kolorze szarym, a szerokie były prawdopodobnie czerwone i żółte (ryc. 9). Kolumna o gładkim trzonie (północno-zachodnia) mogła być pierwotnie cała czerwona, z wyjątkiem bazy. Na tę czerwień nałożono warstwę rombów w trzech kolorach, powtarzających się naprzemiennie: żółty, niebieski i ziemistoróżowy (ryc. 10). Romby ograniczała ciemna (niebiesko-czarna?) konturówka (ryc. 2) ${ }^{22}$. Sugerowano, że ten bogaty zestaw barw zastosowano, by zasłonić szczelinę w trzonie pękniętym aż do głębokości $30 \mathrm{~cm}^{23}$.

Zatem zarówno powyższe przesłanki, jak i dane wynikające $\mathrm{z}$ literatury przedmiotu pozwalają z dużą dozą prawdopodobieństwa sugerować, że w romańskiej bazylice ściany i filary najpierw pokryto białymi tynkami, prawdopodobnie założonymi jednorazowo po zakończeniu budowy około 2.-3. ćwierci XIII wieku -

${ }^{20}$ Dwa fragmenty składające się ze sobą znaleziono nad gotycką posadzką, w nawie północnej bazyliki (Sulkowska-Tuszyńska 2006, ryc. 48 i 49, s. 56-57). Obecnie znajdują się w miejscowym lapidarium; nie zostały wkomponowane w swoje pierwotne miejsce. Spod żelazistej czerwieni miejscami przebija barwa żółtawa - może jest to relikt pigmentu, efekt „urody” piaskowca lub wynik degradacji warstwy malarskiej.

${ }^{21}$ Najwięcej resztek barwnych zachowało się na kolumnie północno-wschodniej (ryc. 6) - na kapitelu od strony nawy głównej, na trzonie w strefie górnej (personifikacje: Próżna chwała, Zawiść, Nieczystość) i nad bazą (na łuku arkad i na trzonach małych kolumienek - np. Bluźnierstwo). Na kolumnie południowej relikty barwy podobnej do ceglastoczerwonej zachowały się na głowicy (scena Chrztu św.), na archiwoltach środkowego pasa z postaciami (tło za postaciami, np. Mądrość), a w dolnej strefie, na archiwolcie nad Pokora (ryc. 7a-c). Nazwy cnót i przywar podaję za: Zbigniew Sroka (2000).

${ }^{22}$ Bliższe przyjrzenie się umożliwia dostrzeżenie pod rombami plamek czerwieni w szczelinach ubytków, co sugerował Z. Kępiński, potem Cz. Sikorski (Kępiński 1946, s. 205; Sikorski 1994, s. 40). Opisane przez Z. Kępińskiego kolory, w tym około 10 takich rombów na odprysku trzonu, widziałam osobiście w latach 80. XX wieku.

${ }^{23}$ Z. Kępiński, po słynnym odkuciu czterech kolumn w bazylice konwentualnej w Strzelnie, tak uzasadniał „dywanową" dekorację z rombów, widoczną tylko na trzonie gładkiej kolumny międzynawowej (Kępiński 1946, s. 203). 


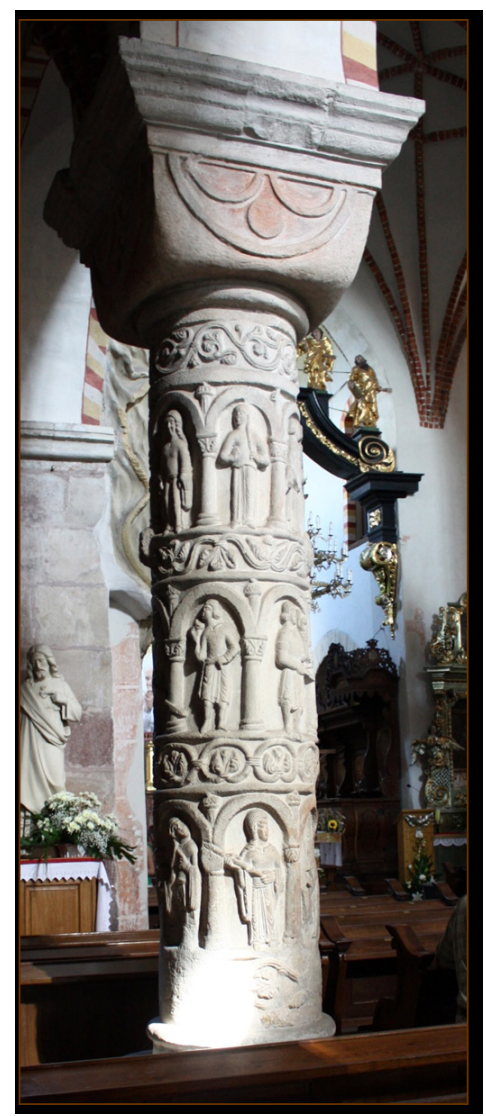

Ryc. 6. Strzelno, bazylika Świętej Trójcy - korpus nawowy. Romanska kolumna północno-wschodnia z personifikacjami przywar ludzkich. Relikty czerwonej warstwy malarskiej widoczne na głowicy. Fot. J. Struwe

w prezbiterium, potem $\mathrm{w}$ transepcie $\mathrm{i}$ w korpusie nawowym $\mathrm{z}$ wieżami. W niektórych miejscach, a z całą pewnością na filarach międzynawowych, na biały tynk nałożono czerwonożelazisty, o grubości około 3-4 mm. Taka kolorystyka dominowała też na czterech kolumnach międzynawowych. Po wielkim pożarze, po którym największe ślady pozostały w masywie zachodnim²4, na głęboko pękniętą gładką kolumnę nałożono ornament w postaci wielobarwnych rombów, by zamaskować defekt.

${ }^{24}$ Gruba warstwa spalenizny w pomieszczeniu pomiędzy wieżami zachodnimi obserwowana podczas nadzoru archeologicznego w 2000 roku oraz spalenizna w próbkach polichromii z pomieszczenia pod wieżą południową (Sulkowska-Tuszyńska 2006, s. 36, ryc. 46, 47; Kiepuszewska 2003, s. 16). 


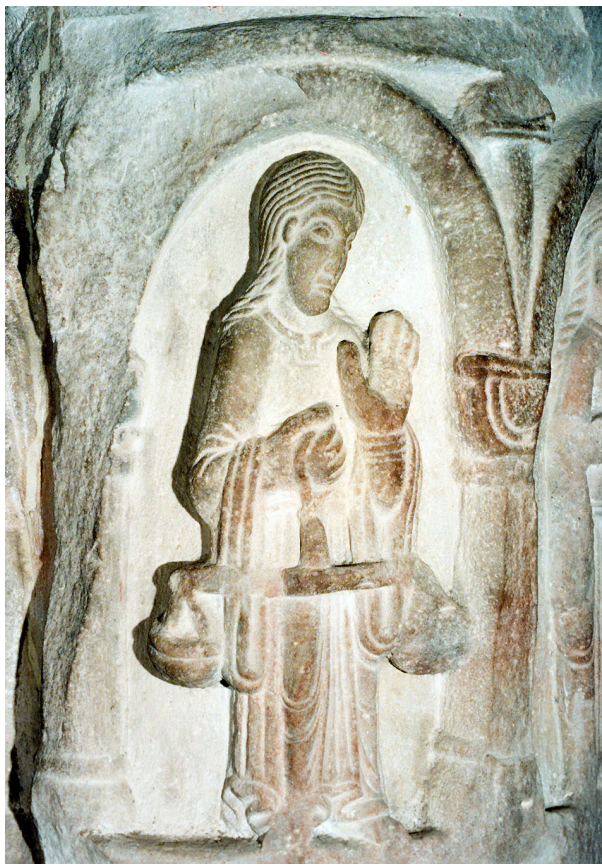

Ryc. 7a. Strzelno, bazylika Świętej Trójcy korpus nawowy. Romańska kolumna południowo-wschodnia - personifikacja Sprawiedliwości. Relikty czerwonej warstwy malarskiej widoczne za kolumienką, po prawej. Fot. K. Sulkowska-Tuszyńska

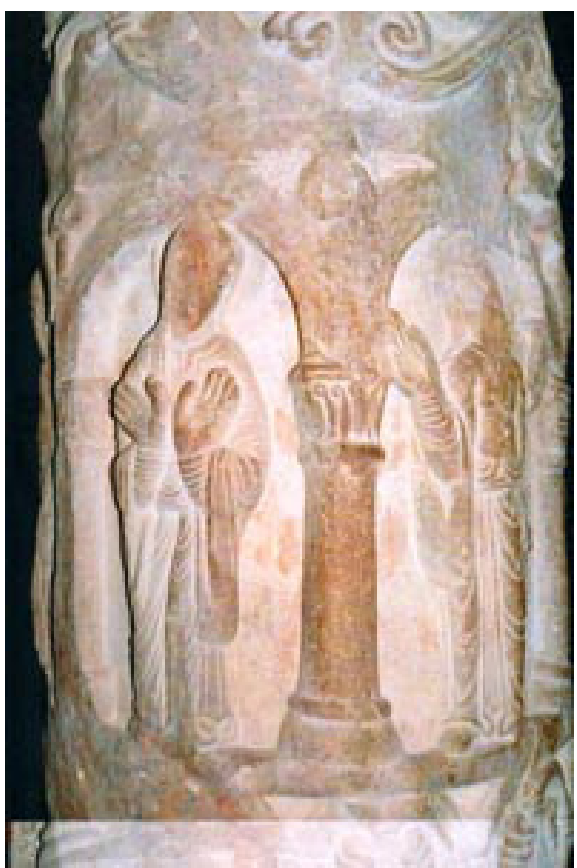

Ryc. 7b. Strzelno, bazylika Świętej Trójcy korpus nawowy. Romańska kolumna południowo-wschodnia - personifikacje Pokory i Pobożności; ślady czerwonej warstwy malarskiej. Fot. K. Sulkowska-Tuszyńska

Pomiędzy prezbiterium a aneksami, dwie gładkie, proste i nieco przysadziste kolumny, pozostawiono w naturalnej szarej barwie ${ }^{25}$. W prezbiterium, w najstarszym okresie, ściany wraz z wielką absydą pokryto tynkiem wapienno-piaskowym o grubości 2-5 mm. Na kamiennym i, w wyższych partiach, kamienno-ceglanym wątku przewiązanym czerwonawą wapienno-piaskową zaprawą, położono tynk „o charakterystycznym ciemnobrązowym zabarwieniu" (Kiepuszewska 2003, s. 15; Orłowska 2003, s. 4, 5). Warstwy malarskie w absydzie, fragmentarycznie i bardzo źle zachowane na tynku, były trudne do zidentyfikowania. $Z$ taką kolorystyką na najniższym poziomie kontrastowała zielona i zielono-ceglasta posadzka ułożona z kwadratowych płytek $(13 \times 13 \times 2,5$ cm: Sulkowska-Tuszyńska 2006, ryc. 26, 27, 64-69, s. 42,

25 Północna kolumna jest zamurowana, widać tylko mały fragment bazy o naturalnym kolorze jasnego piaskowca. Południowa kolumna (przy obecnej kaplicy św. Barbary) w 2001 roku została całkowicie uwidoczniona i podparta mocną metalową konstrukcją. Na jej powierzchni gołym okiem nie widać żadnych przebarwień. 


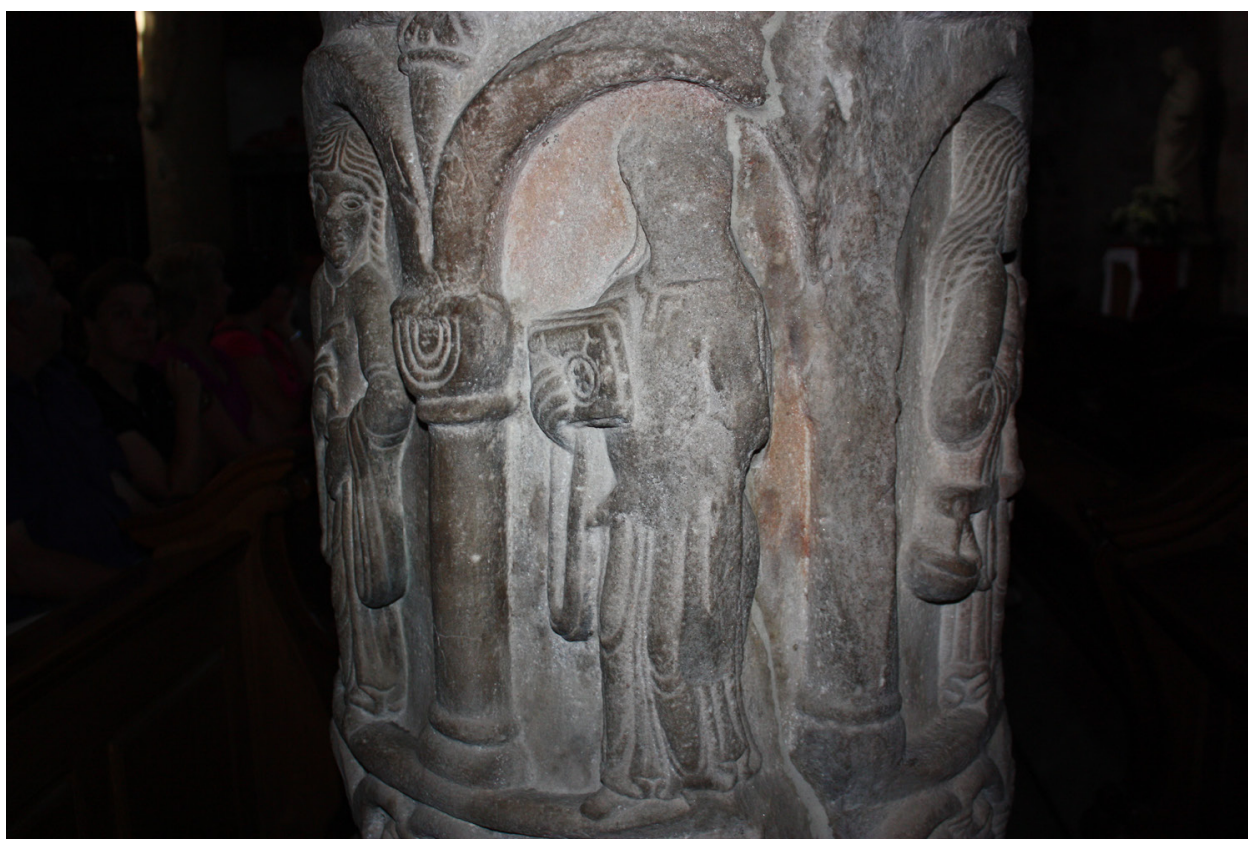

Ryc. 7c. Strzelno, bazylika Świętej Trójcy - korpus nawowy. Romańska kolumna południowo-wschodnia - personifikacja Roztropności. Czerwona warstwa malarska widoczna na powierzchni tła, pod arkadą. Fot. K. Sulkowska-Tuszyńska

65-67; 2009, ryc. 10, s. 465) ${ }^{26}$ (ryc. 11). Dopełnieniem kolorystyki całej bryły kościoła, w okresie pomiędzy XIII a XIV stuleciem, były duże fryzowe płytki ceramiczne $\mathrm{z}$ arkadkami, pokryte zielono-brązowym szkliwem, umieszczone na elewacjach, prawdopodobnie poniżej dachu (Sulkowska-Tuszyńska 2006, s. 51-52, ryc. 40, 41 i s. 38-39, ryc. 20, 21) ${ }^{27}$ (ryc. 12, 12a). Podsumowując uwagi o kolorystyce romańskiej bazyliki Świętej Trójcy w Strzelnie, należy podkreślić, że uzyskane wnioski oparte są na analizie występowania dość licznych, ale niewielkich reliktów, zachowanych i dostrzeżonych w różnych miejscach w kościele, od pierwszego najstarszego poziomu użytkowego aż do poddasza. Niestety, nie mamy żadnych wiadomości o polichromiach figuralnych tego okresu, zatem możliwości wnioskowania są zawężone w stosunku do domniemanego stanu pierwotnego i ściennego malarstwa zachowanego w innych kościołach na terenie Polski. Wiemy, że w bazylice strzeleńskiej, po zakończeniu jej budowy, w XIII wieku ${ }^{28}$ dominującym

${ }^{26}$ Płytki te były ozdobione plecionką i motywami zoomorficznymi (gołębie, orły, jelenie).

27 Wysokość płytek od 37 do $52 \mathrm{~cm}$. Podczas badań archeologicznych płytki takie zalegały wzdłuż murów kościoła, od zewnątrz.

${ }^{28}$ Analizując rzeźbiarską dekorację na zewnątrz i we wnętrzu kościołów z XI-XII wieku, M. Walicki podaje przykład Strzelna (Walicki 1971, s. 230). Należy podkreślić, że po badaniach 
kolorem użytym do ozdobienia architektury była czerwień, a biel prawdopodobnie pokrywała większe powierzchnie ścian i stanowiła tło opracowania malarskiego. Detal rzeźbiarski i architektoniczny kolorowano różnymi odcieniami czerwieni; jest możliwe, że był to ten sam kolor, ale w zależności od gęstości farby, rodzaju i barwy tła oraz grubości nakładanej warstwy, dawał różne efekty, co może potwierdzać stan kolorystyki w Strzelnie ${ }^{29}$. W mniejszym stopniu używano czerni i ugru, a do „rombowej” dekoracji także błękitu i różu (ryc. 2). Wydaje się, że na tle powłok malarskich zachowanych w różnych obiektach architektonicznych na terenach polskich, ta „strzeleńska” dekoracja była wyjątkowa. Taki typ zdobienia ściennego nie ma - jak dotąd - analogii na terenach polskich. Jest natomiast bardzo podobny do żółto-niebiesko-białych rombów pokrywających trzony kolumn w kościele w Poitiers, w Owernii; różni się motywami lilii, dodatkowo nałożonymi na niektóre romby (Świechowski 2014, s. 211, ryc. 11) ${ }^{30}$.

$\mathrm{Na}$ odbiór kolorystyki w bazylice znaczący wpływ miały witraże, o których wiemy zaledwie tyle, że w niewielkim zakresie mogły być używane od XIV wieku i były wstawiane $\mathrm{w}$ ołowiane ramki o szerokości $4-5 \mathrm{~mm}^{31}$. Architektura i jej rzeźba pozostawały w polu oddziaływania naturalnego światła, które dawało różne efekty w zależności od pory dnia i roku, kierunku i kąta padania promieni słonecznych, wielkości otworów okiennych, stopnia ich rozglifienia itp. Światło, konieczne szczególnie w prezbiterium, nadawało blasku wnętrzu, gdyż jako boskie, uświęcało przestrzeń sakralną (Sienkiewicz 2017, s. 425 i nn.). Tak jak witraże rzucające kolorowe plamy na wnętrze sacrum przypominały o boskim pierwiastku natury, tak odpowiednio oświetlana architektura wraz z kolorowaną rzeźbą przemawiała do modlących się, wzmacniając ich religijne odczucia. Wskazując, że środkami kształtowania wyrazu artystycznego, szczególnie od XIII wieku, było polichromowanie rzeźbiarskich elementów architektonicznych łączone z eksponowaniem naturalnych barw kamienia, Michał Walicki podkreślał, że: „architektura współgrała z jej dekoracją, obie stopione [były] światłem i barwą" (Walicki 1971, s. 236-237). Romańska bazylika Świętej Trójcy w Strzelnie jest pięknym przykładem takiego współgrania.

Wyżej wzmiankowano już problem z datowaniem, który rozwiązany zostanie na podstawie trzech argumentów. W konsekwencji konieczne będzie przesunięcie chronologii II posadzki i geometrycznych polichromii, dotąd określanych jako

archeologiczno-architektonicznych barwnego wystroju całej bazyliki strzeleńskiej nie można łączyć z XII, a dopiero z XIII stuleciem i najwcześniej z 2. ćwiercią tego stulecia.

${ }^{29}$ Te kwestie wyjaśniłyby specjalistyczne badania.

${ }^{30}$ Z. Świechowski wskazuje Poitiers jako bardzo dobry przykład rekonstrukcji wyrazistej kolorystyki trzonów i kapiteli oraz naśladowania barwnego marmuru w kościołach Owernii. Autor pochwalił wiarygodność tamtego rozwiązania, w odróżnieniu od zabiegów restauracyjnych polegających na zbijaniu tynków i całkowitym niszczeniu zabytkowych polichromii (Świechowski 2014, s. 210; 2012).

${ }^{31} \mathrm{~W}$ jednej z warstw (XIV wiek) było zaledwie kilka niemal czarnych cienkich szybek $(2 \mathrm{~mm})$, które po wyjęciu na powierzchnię całkowicie się rozwarstwiły. 


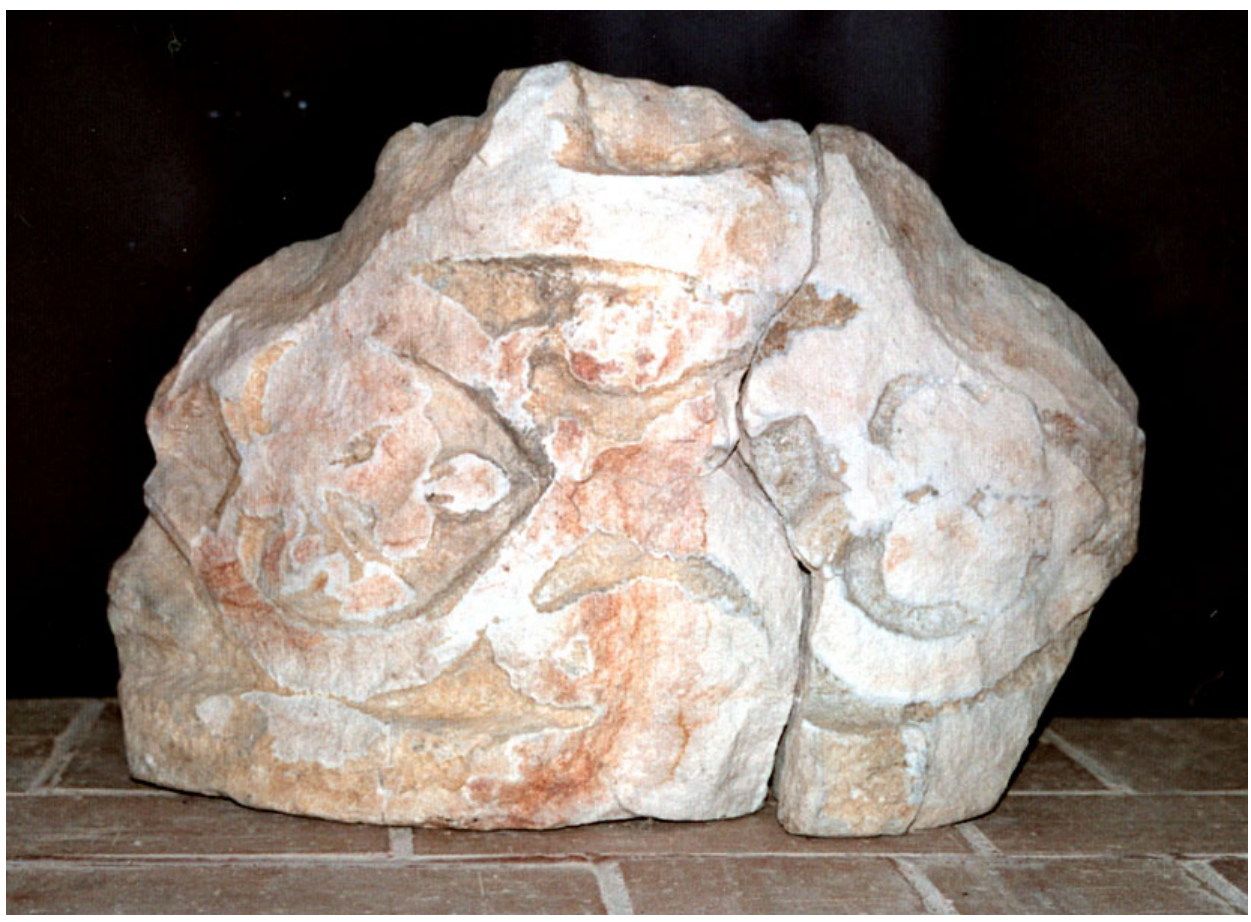

Ryc. 8. Strzelno, bazylika Świętej Trójcy. Ubytek z trzonu romańskiej kolumny północno-wschodniej. Widoczne relikty warstwy malarskiej. Fot. K. Sulkowska-Tuszyńska

romańskie. Z kilku położonych w bazylice II posadzka zachowała się najlepiej, w wielu miejscach przestrzeni sakralnej, i najlepiej jest rozpoznana. Z układu stratyfikacyjnego wynika, że została położona na piasku, pod którym są jeszcze trzy, a w innym miejscu cztery warstwy zalegające nad humusem pierwotnym lub nad koroną fundamentu. $\mathrm{Na}$ obszarze transept/nawa południowa pod podsypką piasku II posadzki zachowała się szarobrunatna glina, cienka warstwa spalenizny, a niżej warstwa zaprawy z drobnymi kamieniami - pierwotny poziom użytkowy. Natomiast przy zachodniej ścianie kościoła były to dwie warstwy zaprawy, cienka smuga spalenizny po pożarze i humus pierwotny ${ }^{32}$. Wyższa wylewka zaprawy mogła być pierwotnym poziomem użytkowym, któremu w prezbiterium odpowiadała I posadzka, nieuchwycona in situ, zachowana w postaci luźnych fragmentów szkliwionych kwadratowych płytek (13 x $2,5 \mathrm{~cm})$, ozdobionych motywami zoomorficznymi lub plecionką (Sulkowska-Tuszyńska 2006, s. 42, 65-67; ryc. 26, 27, 64-69). Uformowanie się kilku jednostek kulturowych pomiędzy humusem a II posadzką

32 Wzdłuż ściany zachodniej, pod domniemaną emporą, w efekcie pożaru kościoła pozostała gruba warstwa (do $20 \mathrm{~cm}$ ) spalonego drewna; w transepcie i wokół filarów wschodnich ta warstwa miała zaledwie 2-4 cm, ale była bardzo dobrze czytelna. 
wymagało dłuższego upływu czasu od ukończenia budowy masywu zachodniego w 2.-3. ćwierci XIII wieku.

W poszukiwaniu podstaw do korekty datowania uwzględniono też ceramikę, która nie jest czułym wyznacznikiem chronologicznym, ale była w późnym średniowieczu typowym i masowym wyrobem. Były to fragmenty naczyń stalowoszarych zalegające pod II posadzką, w podsypce piasku ${ }^{33}$. Na obszarze zajmowanym przez konwent strzeleński, na terenie całego claustrum takie naczynia najwcześniej były obserwowane $\mathrm{w}$ zespole jednostek formujących się od około 4. ćwierci XIII wieku do 4. ćwierci XIV wieku (Dubikajtis, Dubikajtis i Sulkowska 1990, s. 36-37; Sulkowska-Tuszyńska 1997, s. 61-64; 148-149). Ich rozwój przypadał w XV wieku. Po rozebraniu muru od wschodu ograniczającego przestrzeń empory zachodniej, w analizowanym miejscu, tak jak w całej bazylice, położono II posadzkę (Sulkowska-Tuszyńska 2006, ryc. 45 - wkładka). Należy przyjąć, że od zakończenia budowy masywu zachodniego, poprzez wyposażanie wnętrza, w tym budowę empory, do jej rozebrania po pożarze (koniec XIII wieku?) mogło upłynąć wiele lat, zanim konwent był gotowy udźwignąć koszty kapitalnego remontu całej przestrzeni świątyni, wraz z nową posadzką.

Czas położenia II posadzki możemy zawęzić dzięki monecie znalezionej pod posadzką, w nienaruszonym odcinku stratyfikacji, w obrębie południowego ramienia transeptu, tuż przy południowej ścianie ${ }^{34}$. Był to srebrny fenig brakteatowy ${ }^{35}$ z równoramiennym krzyżem o rozszczepionych końcach, bez daty, emitowany przez zakon krzyżacki od roku 1416 do około 1450 (średnica 14,4 mm, 0,28 g, nr inw. 143/83) (Paszkiewicz 2013, s. 148, 153; Katalog: Hala Targowa 90, 91, $154 c$, s. 385, 387). Z wyżej podanych trzech argumentów wynika jasno, iż dochodzące do II posadzki tynki z geometrycznymi motywami mogą być datowane najwcześniej po roku 1416 lub po około 1450. A jak należy wytłumaczyć fakt, że te kolorowe tynki-bonie i trójbarwne pasy widziane były przez kilku badaczy, na poddaszu, ponad gotyckim sklepieniem? Być może przy położeniu nowej warstwy malarskiej wymieniono stare belki stropu na nowe, mocując je w dawnych gniazdach. Po czasie, może krótko po zbudowaniu i założeniu sklepienia nad kaplicą Świętej Barbary (po 1459), w nawach też wymieniono strop na sklepienie, opierając całą konstrukcję znacznie niżej niż gniazda stropu. Jest też możliwe, iż zaraz po demontażu stropu, a przed założeniem sklepienia ściany pomalowano, boniami sięgając powyżej gniazd belek ${ }^{36}$. Te geometryczne polichromie zdobiły ściany

33 Strzelno - 1983: Dokumentacja rysunkowa: rys. nr 183/83 - warstwa nr 5, notatka: Dziennik wykopów 1983 z dnia 20-23.08.1983. Opis - Jerzy Dubikajtis.

34 Była to trzecia warstwa ponad wkopem fundamentowym (szary piasek, wyżej przepalona glina): brązowy piasek z gruzem ceglanym i spalenizną, na którym położono płytki ceglaste, bez zdobień i szkliwa $(21 \times 21 \times 4 \mathrm{~cm})$.

35 Wcześniej datowany na XIV-XV wiek (Musiałowski 1990, s. 99, 108).

${ }^{36} \mathrm{Tu}$ decydujące znaczenie miałoby datowanie (dendrochronologia) resztek belek w gniazdach i drewnianych elementów związanych z zakładaniem sklepienia. 


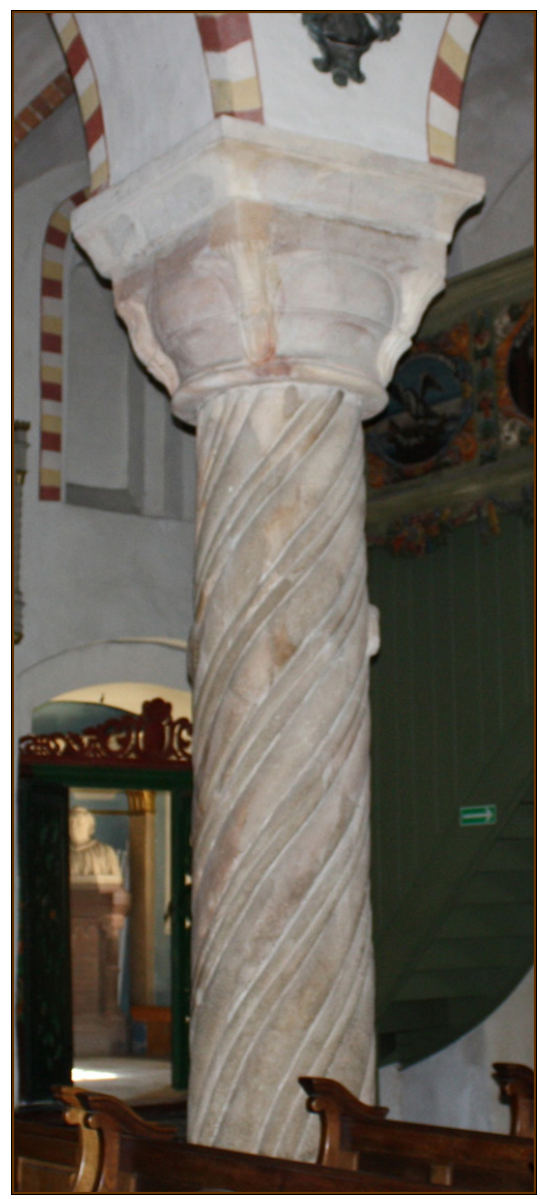

Ryc. 9. Strzelno, bazylika Świętej Trójcy - korpus nawowy. Romańska kolumna południowo-zachodnia. Warstwa malarska widoczna na trzonie i głowicy. U góry i w głębi trójkolorowa polichromia - rekonstrukcja malarska po pracach konserwatorskich. Fot. J. Struwe

kościoła co najmniej do 1575 roku $^{37}$ (Sulkowska-Tuszyńska 2006, s. 123-124, ryc. 138-140).

Przegląd literatury przedmiotu dotyczącej kolorystyki średniowiecznych sakralnych wnętrz na terenach polskich uświadamia nam, że dominującymi kolorami

${ }^{37}$ Przekonują o tym daty wyryte przez pątników na polichromowanych ścianach, zachowane na południowo-wschodnim filarze. 
używanymi we wnętrzach architektury romańskiej i wczesnogotyckiej była biel pełniąca rolę tła, i czerwień, którą kolorowano detal rzeźbiarski i architektoniczny (patrz literatura niżej i Poksińska 1993, s. 24), co zdaje się potwierdzać stan kolorystyki w Strzelnie. Używano także czerni (głównie do konturów) oraz ugru; inne barwniki były stosowane rzadziej i tylko w niektórych środowiskach. Początki stosowania kolorów do ozdabiania wnętrz sakralnych na polskich terenach nie są i chyba nie mogą być - dobrze rozpoznane z powodu słabego stanu zachowania monumentalnej architektury wczesnopiastowskiej, którą znamy przede wszystkim z fundamentów, a niekiedy z ich negatywów (!). Obraz architektury z X i 1. połowy XI wieku wraz z postępem badań się zmienia i uaktualnia, ale jej wystrój nadal nie jest rozpoznany, tym bardziej że zmianie ulega także datowanie odkrytych reliktów. W przedromańskiej katedrze w Gnieźnie, na reliktach identyfikowanych jako rotunda Mieszka I zachował się tynk z pigmentami. O bogatej kolorystyce wnętrza najmłodszej katedry datowanej na 2. połowę XI wieku mogą świadczyć tynki z zachowanymi śladami polichromii, natomiast mozaikowe posadzki (granat zieleń - żółć), unikatowe w środkowej Europie, były łączone z wystrojem katedry z czasów Bolesława Chrobrego. Z kaplicą na Ostrowie Tumskim, usytuowaną obok pierwszej katedry poznańskiej, datowanej przed lub po 1000 roku, wiązane są fragmenty tynku z pigmentami typowymi dla malarstwa ściennego (biel wapienna, czerwień żelazowa, unikatowy wówczas błękit-lazuryt), znalezione w kontekście datowanym na podstawie analogii od 2. ćwierci IX do 1. połowy XI wieku (Żurowski 2002, s. 70, 72, ryc. 21-26; Walicki 1972, s. 226; Kóčka-Krenz 2003, s. 73, $79,80)$.

Poza wcześniejszymi i wyjątkowymi przykładami łączonymi z X - 1. połową XI wieku, od schyłku XI wieku potwierdzone jest częstsze barwienie monumentalnej architektury sakralnej (absydy, ściany tęczowe, ściany naw), któremu sukcesywnie towarzyszyło kolorowanie rzeźby i detali (portale, tympanony, kolumny, zworniki itp.). W XII wieku praktyka malarskiego zdobienia sakralnych wnętrz rozpowszechniała się na ziemiach polskich. Niestety, we wnętrzach romańskich budowli w Polsce przetrwało bardzo mało świadectw tego malarstwa; tym bardziej na zewnątrz budowli. $Z$ nielicznych reliktów polichromii, jakie przetrwały, wiele zostało mocno zmienionych przez czas; najczęściej pozwalają one tylko odnotować ich występowanie, ale uniemożliwiają odtworzenie bliższego obrazu. W lepszym stanie znajdują się polichromie z XIII wieku, które na terenach polskich łączy się głównie z kręgami kultury klasztornej i uprawianej tam erudycyjnej teologii, pokazywanej w sacrum w formie rzeźby i figuralnej polichromii (Walicki 1971, s. 230-238).

Najbliżej Strzelna, w kolegiacie w Kruszwicy, były jakieś motywy ornamentalne na ścianach naw bocznych, a na arkadach międzynawowych inne, imitujące wątki architektoniczne. Także w bazylice Świętego Wita, na tynkach odkryto niezidentyfikowane freski z konturami wykonanymi czarną farbą (Kaczmarek 2004, s. 322-323, ryc. 6). W Gnieźnie, we wnętrzu jakiegoś obiektu kamiennego 


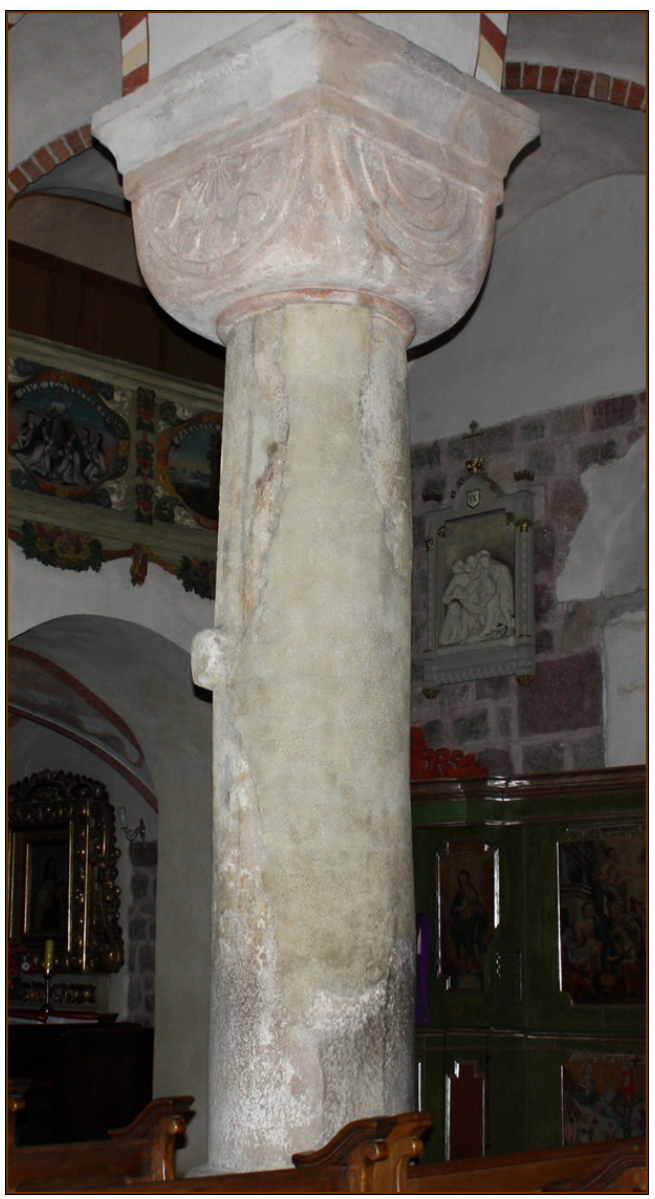

Ryc. 10. Strzelno, bazylika Świętej Trójcy korpus nawowy. Romańska kolumna północno-zachodnia. Warstwa malarska widoczna na głowicy. Na trzonie duży plaster tynku - ślad po naprawie pęknięcia. Fot. J. Struwe

usytuowanego w otoczeniu kościoła Świętego Jerzego odkryto polichromowane, niemożliwe do określenia tynki identyfikowane $\mathrm{z}$ okresem przedromańskim (Sawicki 2004, s. 147-149, 154). W katedrze gnieźnieńskiej, na detalach wykonanych z jastrychu w połowie XIII wieku, stwierdzono szczątkowe polichromie. Odnaleziono też wspaniałe szkliwione płytki posadzkowe łączone $\mathrm{z}$ wystrojem katedry w XII-XIII wieku (Janiak 2004, s. 125-126; 2009, s. 169). W wielkopolskim opactwie cystersów w Łeknie, w domniemanym oratorium, w XII wieku polichromowane 


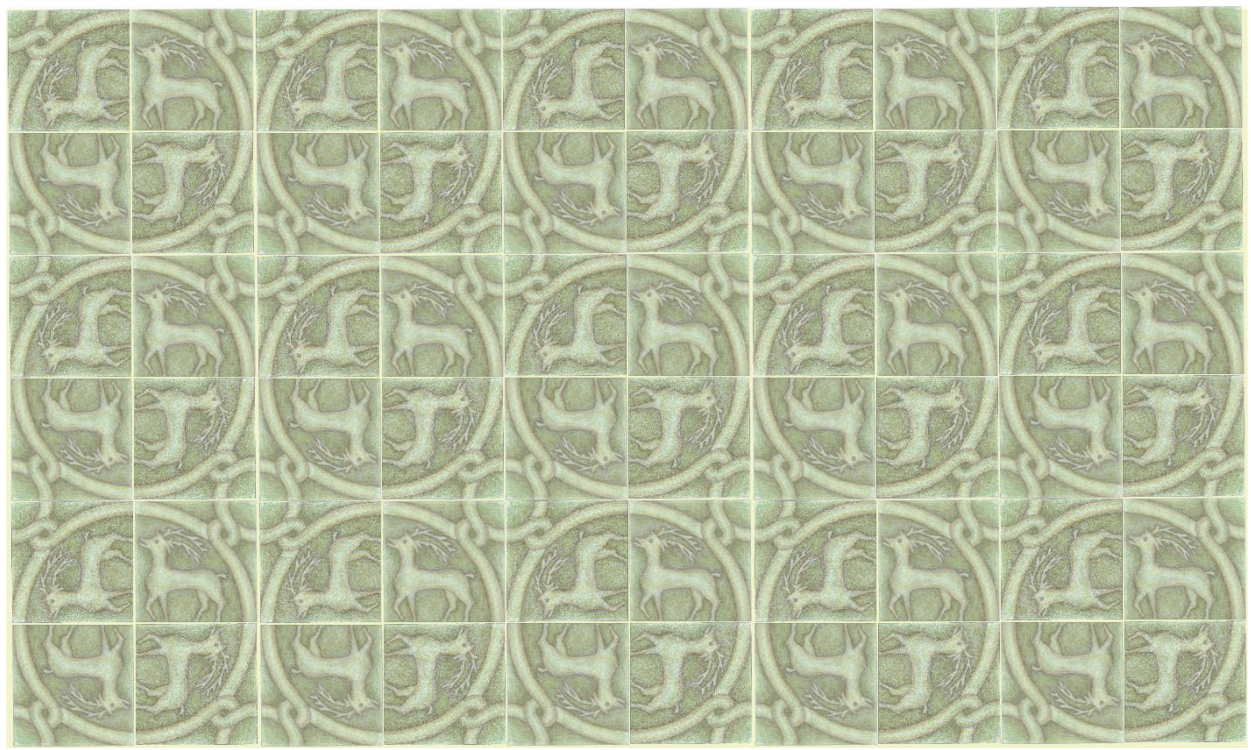

Ryc. 11. Strzelno, bazylika Świętej Trójcy - posadzka z motywem jeleni. Rekonstrukcja K. Sulkowska-Tuszyńska, rys. E. Szewczyk

były detale (wielokrotnie nakładana biel, żółcień i czerwień w dwóch odcieniach), wykazujące znaczne podobieństwa do gnieźnieńskich z katedry (Wyrwa 2004, s. 227-228).

W Polsce centralnej, w Tumie pod Łęczycą, w majestatycznej bryle kolegiaty z XII wieku, w konsze absydy zachodniej umieszczono wizję Sądu Ostatecznego, z wyraźnie widoczną postacią Chrystusa otoczoną wielką mandorlą. Na białym tynku zastosowano tam konturowe malarstwo w kolorze rdzawoczerwonym, niebieskim, minii i zielonym. Także w mazowieckim opactwie kanoników regularnych w Czerwińsku, w monumentalnej dekoracji malarskiej w kościele (zieleń, błękity, róż; 1./2. połowa XII wieku) można rozpoznać Sąd Ostateczny, męczeństwo Szczepana, Wawrzyńca i inne tematy; ślady polichromii zostały też na portalu i nad łukiem tęczowym (Świechowski 1963, s. 303, ryc. 768-771; 2000, s. 264-265, 569, 611 , ryc. $741-743$, s. 52,352 , ryc. $36-38$; 2009, s. 59-65, ryc. 38-40; Walicki 1971 , s. 230-232; il. 5; Pietrusińska 1971, s. 681; Mroczko 1972, s. 33-38, il. 1 - kolor i il. 27,28$)$.

Jedyne zachowane w Krakowie polichromie (XII wiek), wyjątkowo żywe, przypominające tęczowe barwy (pasy: żółcień, zieleń i czerwień), stwierdzono w małym kościele Świętego Andrzeja, w konsze dawnej absydy (Rodzińska-Chorąży i Włodarek 2009, s. 282-283, ryc. 2, 3). Szczególna, bo zachowana na powierzchni aż $9 \mathrm{~m}^{2}$ i wykonana na zewnętrznym murze wieży, jest polichromia $\mathrm{w}$ znakomitej kolegiacie Świętego Marcina w Opatowie (Sąd Ostateczny: Kamińska 2009, 


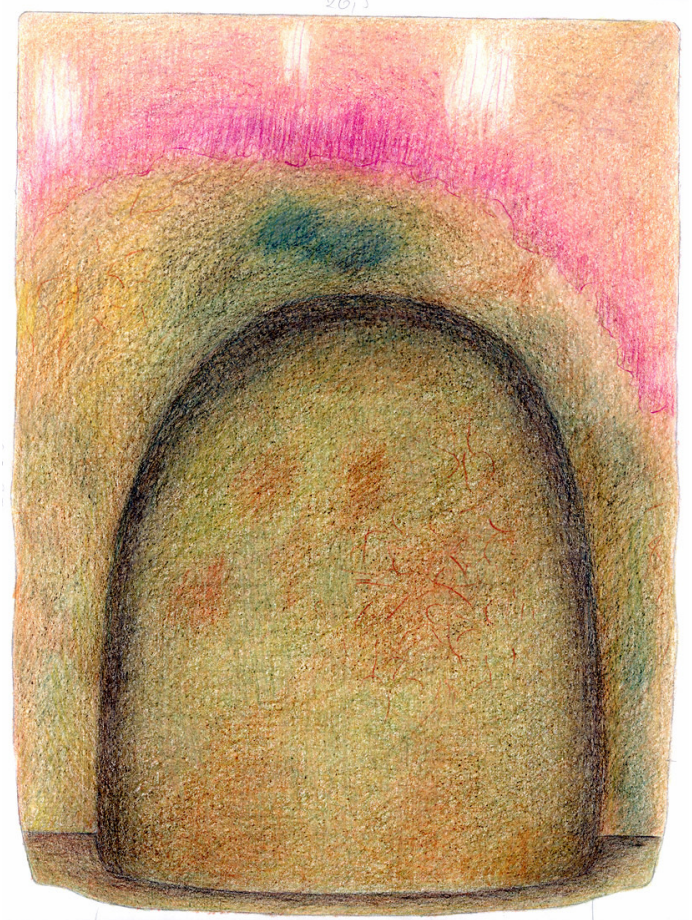

Ryc. 12a. Strzelno, bazylika Świętej Trójcy płytka ścienna z motywem całej arkady.

Rys. E. Szewczyk

s. 351). Z wykonanych na ceglanym wątku zwracają uwagę freski z XIII stulecia zachowane w kościele Świętego Jakuba w Sandomierzu, na podniebiu portalu zakrystii (florystyczne motywy - zieleń i czerwień: Świechowski 2000, s. 213, 532, ryc. 519a; 2004, s. 409, 410, ryc. 521).

Relikty polichromii znane są też z wielu kościołów klasztornych z XII - 1. połowy XIII wieku, gdy rozpowszechniało się malarskie zdobienie wnętrz sakralnych, nierzadko na wysokim poziomie artystycznym, na Śląsku, w Trzebnicy i w Małopolsce - w Jędrzejowie, Sulejowie i w Wąchocku. W opactwie cysterek w Trzebnicy, w 1. połowie XIII wieku w kościele były polichromie w kolorach czerwonym, czarnym oraz, rzadko występującymi, ciemnoniebieskim i zielono-niebieskim. W tym samym czasie cystersi w Wąchocku w klasztornych krużgankach i w kapitularzu mieli podobną kolorystykę (czerwień, czerń, zieleń i żółcień: Pietrusińska 1971, s. $768^{38}$, 774; Walicki 1971, s. 510; Świechowski 1963, s. 68, 318, ryc. 806;

${ }^{38}$ Niebieski i zielony barwnik stosowany w Trzebnicy M. Poksińska łączy dopiero z XV stuleciem (Poksińska 1993, s. 32). 


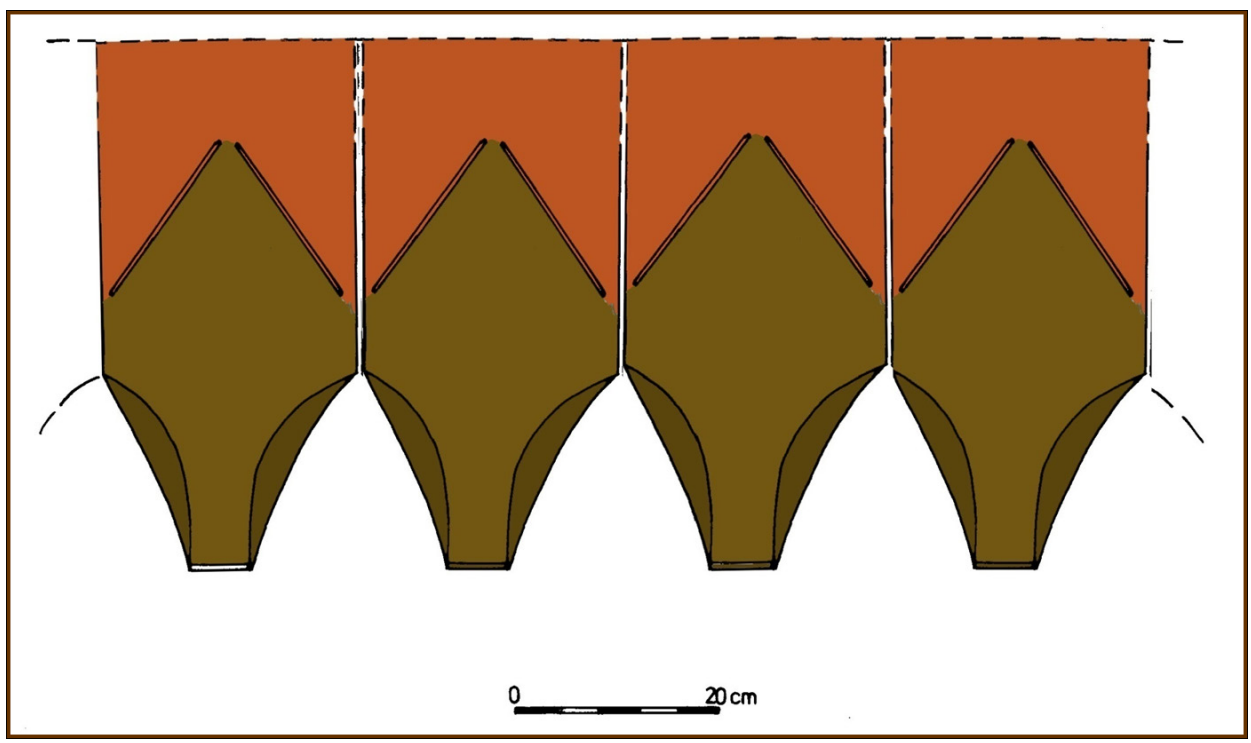

Ryc. 12b. Strzelno, bazylika Świętej Trójcy - fryz z arkadek „z wąsami”. Oprac. graficzne M. Tuszyński

Białoskórska 1960, s. 40). Zwyczaj kolorowania ścian architektury notowany w XII, a głównie w XIII wieku, jest też potwierdzony w małych, parafialnych kościołach (np. Marwice na ziemi lubuskiej i Moryń koło Gryfina, na Pomorzu Zachodnim, Tropie nad Dunajcem) (Świechowski 1963, s.168, ryc. 394, 998, 399; Walicki 1971, s. 237-238; Świechowski 2009, s. 321, 322, ryc. 410, 413). W Małopolsce, w cmentarnym kościele we wsi Sędziszowa-Świerzawa, w absydzie zachowana jest wielokolorowa scena o trzech strefach (Chrystus w wielkiej mandorli, stworzenie ptaków i ryb, pas dekoracji roślinnej), datowana na 2. ćwierć XIII wieku (Świechowski 2000 s. 218, ryc. 537-539; 2009, s. 421, 540, 542, 543). Wysokim poziomem artystycznym cechują się też sceny zachowane w jednonawowym kościele Świętej Magdaleny i Świętego Mikołaja w Dziekanowicach koło Myślenic, datowane na XII/XIII - 1. połowę XIII wieku (Narodziny Chrystusa, Zwiastowanie, Pokłon Trzech Króli: Świechowski 2009, s. 66-68, ryc. 45).

Elementem kolorystyki wnętrz, poza polichromią ścienną i malowaną rzeźbą, były naturalne walory różnie zestawianych skał, zastosowane $\mathrm{w}$ bazylice $\mathrm{w}$ Strzelnie i widoczne w wielu wspomnianych tu budowlach, czasami w bardzo silnych kontrastach kolorów, czego najwyraźniejszym przykładem są mury kościoła u cystersów w Wąchocku i portale wykonane ze skał o różnych kolorach, jak np. w Sulejowie. Wiemy, że w katedrze we Wrocławiu w XII wieku do wyrobu 


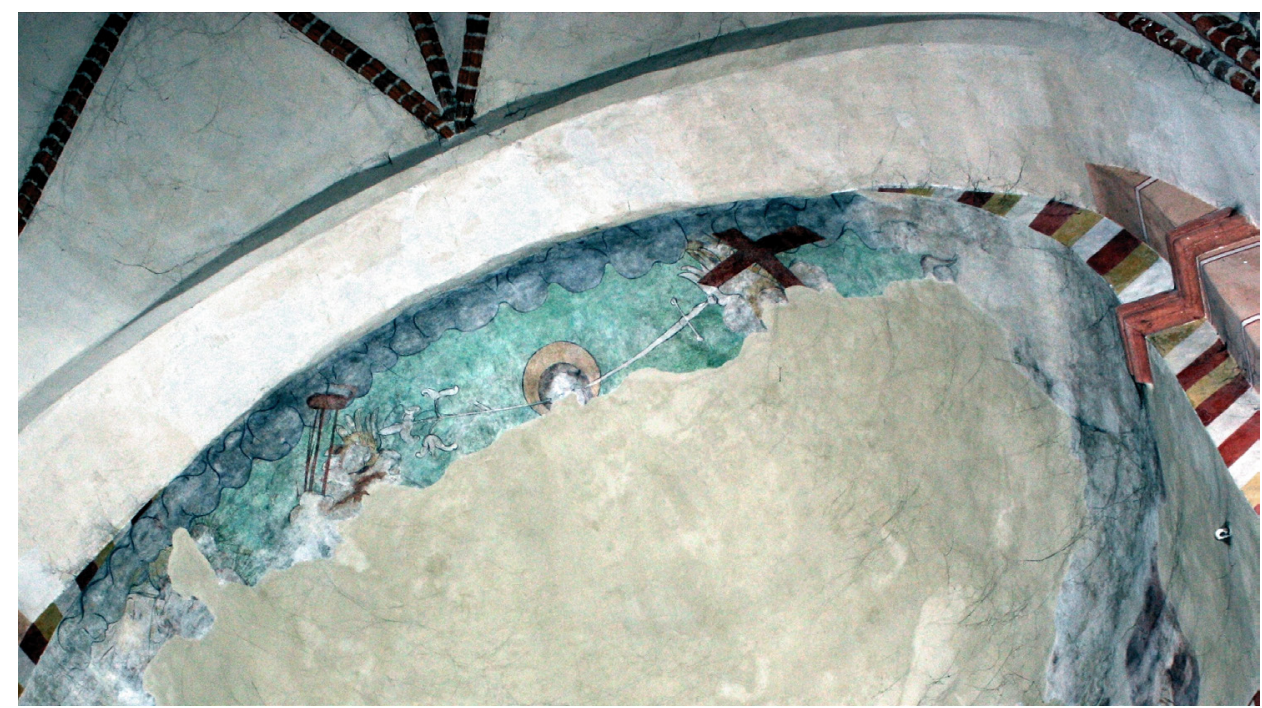

Ryc. 13. Strzelno, bazylika Świętej Trójcy - prezbiterium. Sklepienie absydy - zachowany fragment sceny figuralnej na malachitowym tle: Sąd Ostateczny - Chrystus w żółtej (złotej?) aureoli, pomiędzy mieczem a kwitnącą białą lilią. Po prawej, u dołu, relikt sceny w ciemnej tonacji - brązy i czerwienie. Stan po konserwacji 2003. Na prawym brzegu fotografii polichromia geometryczna - rekonstrukcja barwna. Fot. J. Struwe

detali używano czerwonego piaskowca ${ }^{39}$, a do wielkopolskiego klasztoru w Lubiniu benedyktyni sprowadzali piaskowiec różowy i biały. Podobnie zdobiono niektóre wiejskie kościoły (np. Moryń koło Gryfina, na Pomorzu Zachodnim) (Świechowski 2000, s. 570, 571, ryc. 621, 624; Małachowicz 2009, s. 104-105, ryc. 7; Kurnatowska 2009, s. 235; Świechowski 2000, s. 494, 495, ryc. 413, 495).

Na zakończenie, po krótkim przeglądzie literatury i obserwacjach stanu zachowania malowideł nabieramy przekonania o słuszności sądu, że współczesny pogląd o surowych kamiennych ścianach kościołów, zwłaszcza w XII i XIII wieku, jest absolutnie błędny, bo w rzeczywistości, w chrześcijańskiej Europie kościoły były budowane jako polichromiczne i do XV wieku były ,wielobarwnymi świątyniami koloru". Z czasem, niestety, stały się jednobarwne (Pastoureau 2006, s. 9, 10). Niemal w całej Europie znany jest ten nieprawdziwy efekt działań niekonserwatorskich, kiedy to w XIX wieku średniowieczne polichromie celowo pokrywano nowym tynkiem lub skuwano je, aby odsłonić bloki kamienne, zgodnie z błędnym przekonaniem o surowości architektury romańskiej, pozbawionej tynków i kolorystyki. W istocie, dyspozycja wnętrza monumentalnej architektury romańskiej i gotyckiej w Europie była o wiele bardziej kolorowa niż wyobrażano sobie w XIX-XX wieku.

39 Tu też na cienkim tynku stwierdzono bliżej niezidentyfikowane malarstwo ścienne (Małachowicz 2009, s. 104-105). 
Malowidła zdobiące wnętrza były wielokrotnie uszkadzane, przemalowywane lub przenoszone (Fossi 2006, s. 70) ${ }^{40}$. Przysłaniano je wysokimi nastawami ołtarzy ${ }^{41}$ lub epitafiami ${ }^{42}$. Można zaryzykować przypuszczenie, że z początkiem reformacji bogata kolorystyka wnętrz zaginęła pod nowymi tynkami - protestanci, przejmując katolickie kościoły, przykrywali nimi polichromie ${ }^{43}$.

Kolor stosowany na rzeźbie i w malarstwie ściennym w architekturze epoki średniowiecza miał fundamentalne znaczenie dla rozwoju sztuki i umysłowości tamtej epoki: zdobił, informował, ułatwiał mistyczne przeżycia; malowidła kształtowały mentalność społeczności (Karłowska-Kamzowa 1984, s. 7-10; Rzepińska 1989, s. 110-172). W każdej grupie społecznej funkcja koloru było wskazywanie, uwypuklanie, hierarchizowanie. Kolor nie był ani neutralny, ani jednoznaczny; służył do klasyfikowania, oznaczania, porządkowania, do wyznaczania tożsamości zbiorowej i hierarchii. Michel Pastoureau w wyniku dogłębnych studiów nad kolorem przekonywał, że kolor jest złożoną rzeczywistością kulturową i nie poddaje się generalizacji. Analizowanie koloru stwarza wiele problemów metodologicznych i dokumentacyjnych, tym bardziej że dawne kolory bardzo się zmieniły. Kolor miał $\mathrm{w}$ średniowieczu sens tylko $\mathrm{w}$ zestawieniu $\mathrm{z}$ innymi barwami, dlatego na dawne obrazy nie mogą być nakładane dzisiejsze klasyfikacje. Nie wszystkie kolory miały taki sam status - prawdziwe były barwy świeże, świetliste, trwałe i dające radość. Takie kolory stosowano w kościołach. Wartość koloru i jego piękno osadzano w moralności i religii. Prawdziwie piękne były tylko barwy natury jako dzieła Stwórcy (Pastoureau 2006, s. 127-145). Według Anny Adamskiej, w okresie średniowiecza regułą było dopuszczanie lub ograniczanie obecności koloru, asceza

${ }^{40}$ Malowano zwykle na mokrym - al fresco, ale też na suchym tynku - al secco. Wielkoformatowe malarstwo na tynkach - często konturowe, o różnych barwach, zachowało się w wielu miejscach na ziemiach polskich, podobnie jak w Europie, w kościołach katedralnych, klasztornych, w kaplicach, nawet w małych parafialnych kościołach wiejskich; w gotyku rozwinęła się kolorystyka obiektów świeckich. Przedstawiane sceny ze Starego i Nowego Testamentu czy wizerunki świętych kościoła wykonywali zarówno malarze ścienni, jak i miniaturzyści (Fossi 2006, s. 73, i ryc. na s. 70-73).

${ }^{41}$ W Toruniu, w kościele Świętego Jakuba po usunięciu nastaw ołtarzowych (w celu renowacji i konserwacji) w kilku miejscach ukazały się sceny polichromowane lub odcinki fryzów ceglanych inskrypcyjnych (odkrycia firmy Relief w 2019 i 2020 roku).

${ }^{42} \mathrm{~W}$ ten sposób ocalało $(1,3 \times 2 \mathrm{~m})$ zdobienie ścian filarów czerwonożelazistymi tynkami i boniowaniem w bazylice Świętej Trójcy w Strzelnie (odkrycie podczas remontu w 2001 roku; Sulkowska-Tuszyńska 2006, s. 122-125, ryc. 138-140).

43 Doskonałym przykładem tego trendu jest kościół Świętego Jakuba w Toruniu, w wielu miejscach w XIV i XV wieku pokryty ściennymi kolorowymi narracyjnymi scenami. Gdy w 1557 roku przejęli go toruńscy luteranie, zamalowali wszystkie polichromie. Do lat 70. XX wieku odkryto i zabezpieczono wielobarwne sceny, głównie w zachodniej, wieżowej partii i na wschodnim zamknięciu nawy południowej. Do 2020 roku, po kilku latach prac renowacyjno-konserwatorskich, konserwatorzy odkryli kolejne, niestety, w partiach już zniszczone, polichromie: na ścianach filarów międzynawowych, w nawie głównej, w kaplicach, na chórze muzycznym, na sklepieniu kościoła oraz na ścianach zakrystii, w tym sceny wieloelementowe, inskrypcje, znaki, portrety itp. (także w zakrystii). Przypuszczać można, że ogromną rolę w zakrywaniu i niszczeniu sztuki figuratywnej, w tym polichromii w przestrzeni sakralnej, miały ruchy ikonoklastów, szczególnie silne w Europie Północnej, w XVI wieku. 
chromatyczna albo chromofobia. Wartościowano kolory - były kolory brzydkie i ładne, dobre i złe. Tylko kilka kolorów miało jednoznaczną wartość symboliczną: biel oznaczała zawsze sacrum, niebieski od XII wieku stał się królewskim kolorem (głównie we Francji); negatywna była żółć (zła odmiana złota) i rudy. Czerwień, zależnie od odcieni, mogła być zła lub dobra. W tzw. grze kolorów uczestniczyli zwykle wykształceni ludzie, którzy łatwo poznawali mowę barw. Dostępność koloru była znikoma dla niższych warstw, a ich postrzeganie było rezultatem edukacji ustnej podczas kazań (np. niebieski rozumiano jako „maryjny”, a krwista czerwień symbolizowała mękę Chrystusa). Zasadne jest zatem pytanie, czy dziś potrafimy odczytać kolory, których symbolika jest ambiwalentna i zmienna, tym bardziej że nie wszędzie i nie wszystkie barwy były dostępne, a wiele barwników było bardzo kosztownych (Adamska 2015, s. 9-25).

Niech powyższe przykłady, zaczerpnięte z obszernych studiów M. Pastoureau i podążającej w tak wyznaczonym kierunku A. Adamskiej, tłumaczą rezygnację z przybliżania $\mathrm{w}$ tym miejscu symboliki poszczególnych kolorów używanych w bazylice w Strzelnie, tym bardziej że nie są nam znane żadne dokumenty na ten temat (preferencje fundatorów, budowniczych czy magistry panien norbertanek) ${ }^{44}$.

Przestrzeń sakralna bazyliki z rzeźbą o wysokim poziomie artystycznym i moralizatorskim przesłaniu przeznaczona była dla kanonii, do której najpierw wstępowały panny $\mathrm{z}$ rodów książęcych i możnowładczych. To wnętrze służyło uwielbianiu Boga, celebracji liturgii, modlitwie zbiorowej i indywidualnej; polichromowanie podkreślało cechy bryły i artykulację dużych płaszczyzn, ożywiało i rozjaśniało stosunkowo ciemne wnętrze. Ostateczny efekt kolorystyczny danego wnętrza był zapewne wypadkową zastosowania jasnych (?) tynków na ścianach, naturalnych barw kamienia lub cegły, pigmentów dających różne odcienie kolorów nakładanych na kamienną rzeźbę i tynki, proporcji bryły, podziałów wnętrza, a także ilości i kąta padania naturalnego światła. Może, w zależności od okresu i finansowych możliwości środowiska, gustów i wymagań wybierano, zawężano lub rozszerzano paletę barw?

Należy jeszcze zapytać o nieznaną nam kolorystykę prezbiterium. Wydaje się oczywiste, że jasny tynk odnaleziony na ścianie absydy ${ }^{45}$, w XIII-XIV wieku mógł być pokryty polichromiami o religijnej tematyce, zanim $\mathrm{w}$ XV/XVI stuleciu umieszczono tam figuralne sceny. Słuszność takiego przypuszczenia wzmacniają ustalenia o sile tradycji i kontynuowaniu zwyczaju zdobienia sacrum wyobrażeniami figuralnymi, na terenie Kujaw i Wielkopolski, praktykowanym najpóźniej od XII wieku (Karłowska-Kamzowa 1984, s. 112). Niestety, jest to tylko domniemanie (ryc. 13).

Kończąc, należy podkreślić, że w toku niniejszych rozważań udowodniono, iż geometryczne polichromie, dotąd nazywane romańskimi, występujące w całej

\footnotetext{
${ }^{44} \mathrm{Na}$ temat symboliki, wartości i funkcji barw patrz też: Rzepińska 1983, s. 125-131.

${ }^{45}$ Szczątkowo zachowany pod figuralnymi malowidłami datowanymi na XV/XVI wiek.
} 
przestrzeni kościoła, od prezbiterium do ściany zachodniej, w kaplicach i przed portalem głównym, tak jak figuralne w prezbiterium, należy łączyć z XV-XVI wiekiem. Powyższe uwagi, odnoszące się do kolorystyki kościoła Norbertanek w małym klasztornym Strzelnie, miały za zadanie, po pierwsze, przypomnieć, że romańska rzeźba, wielokrotnie już analizowana, w XIII stuleciu nie była, tak jak obecnie jest postrzegana, szara, ale pokryta różnymi odcieniami czerwieni i, prawdopodobnie, żółcieni; wyjątek stanowiły wielobarwne romby na gładkiej kolumnie. Nie wiadomo, czy rombami ozdobiono też inne miejsca. Filary były czerwone, a ściany otynkowane na biało; brakuje przesłanek o ściennych malowidłach figuralnych w XIII-XIV wieku. Ten rzeźbiarski i chromatyczny wystrój uzupełniały zielonkawe posadzki i arkadkowe fryzy.

W XV-XVI stuleciu $\mathrm{z}$ absydy prezbiterium widoczna była wielobarwna scena zbiorowa na malachitowym tle, a we wnętrzu, w wielu miejscach znajdowały się geometryczne zdobienia. W końcu XVI wieku wielokolorowymi trójkątami ozdobiono ołtarz główny i, domniemane, lektorium ${ }^{46}$. Polichromie te należą już do innej epoki, dlatego nie były tu bliżej rozpatrywane (ryc. 13).

Celem artykułu było podsumowanie stanu wiedzy o kolorystyce kościoła zbudowanego dla norbertanek w Strzelnie w XIII-XIV wieku oraz pokazanie reliktów barw zachowanych na rzeźbie, na ścianach nad pierwotnym poziomem użytkowym, co zawdzięczamy archeologicznym odkryciom. Oby zwrócenie uwagi na to zagadnienie zachęciło do dalszych specjalistycznych badań. Do bardzo skromnego stanu wiedzy o kolorystyce romańskiej architektury na Kujawach teraz dodać można kilka ustaleń o strzeleńskich polichromiach. Obecny stan zachowania, a nierzadko proces degradacji fresków w zabytkowych wnętrzach dowodzi, że pilnie potrzebna jest skuteczna i fachowa interwencja ${ }^{47}$, by ocalić od zapomnienia i dalszego niszczenia to, co ocalić jeszcze można i trzeba - specyficzną dawną sztukę, dziedzictwo kulturowe Polski, jakim była kolorystyka w monumentalnej architekturze średniowiecza.

\section{BIBLIOGRAFIA}

Adamska A. 2015, Gra w kolory. Rola barw w średniowiecznym systemie komunikacji społecznej, „Roczniki Historyczne", R. LXXXI, s. 7-34.

Białoskórska K. 1960, Wachock, opactwo cystersów, Warszawa.

Chudziakowa J. 1988, Die romanischen Kirchen in Strzelno und ihre Chronologie, „Archaeologia Polona“ XXVII, s. 221-242.

46 Okresowo kościół Świętej Trójcy służył też parafianom; gdy rotunda została zniszczona, prezbiterium bazyliki zasłonięto lektorium, po którym pozostał tylko fundament na linii transept - nawy (Sulkowska-Tuszyńska 2006, s. ryc. 45 - wkładka, ryc. 70, s. 68). Patrz ryc. 3.

${ }^{47}$ Patrz też ciekawe uwagi o bezpowrotnym niszczeniu polichromii we Francji oraz o potrzebie podjęcia planowych prac w kierunku poszukiwania, zabezpieczenia i skatalogowania średniowiecznych malowideł ściennych w Polsce (Świechowski 2014; Korpała 2014). 
- 1990, Zespól architektury romańskiej w Strzelnie $w$ świetle najnowszych badań, „Acta Universitais Nicolai Copernici", Archeologia 13, s. 5-27.

Dubikajtis J., Dubikajtis J., Sulkowska G. K. 1990, Charakterystyka stratyfikacji kulturowej wzgórza klasztornego $w$ Strzelnie, w: J. Chudziakowa (red.), Z badań nad średniowieczna architektura Kujaw $i$ Wielkopolski Wschodniej, BMiOZ seria B, t. 86, s. 31-88.

Fossi G. 2006, Sztuka romańska i gotycka, Warszawa.

Janiak T. 2004, Problematyka wczesnych faz kościoła katedralnego w Gnieźnie, w: T. Janiak, D. Stryniak (red.), Poczatki architektury monumentalnej w Polsce, Gniezno, s. 85-130.

- 2009, Z badań nad przestrzenią liturgiczną romańskiej katedry w Gnieźnie, w: T. Janiak (red.), Architektura romańska w Polsce. Nowe odkrycia i interpretacje, Gniezno, s. 129-174.

Józefowiczówna K. 1978, Trzy romańskie klasztory, w: Cz. Łuczak (red.), Studia z dziejów ziemi mogileńskiej, Poznań, s. 165-266.

Kaczmarek J. 2004, Poczatki architektury sakralnej w Kruszwicy, w: T. Janiak, D. Stryniak (red.), Poczatki architektury monumentalnej w Polsce, Gniezno, s. 311-332.

Kamińska M. 2009, Kilka uwag na temat architektury romańskiej kolegiaty pw. św. Marcina w Opatowie, w: T. Janiak (red.), Architektura romańska w Polsce. Nowe odkrycia i interpretacje, Gniezno, s. 341-356.

Karczewski D. 2001, Dzieje klasztoru Norbertanek w Strzelnie do poczatku XVI wieku, Inowrocław.

Karłowska-Kamzowa A. 1984, Wielkopolska i Polska centralna, w: J. Domasławski, A. Karłowska-Kamzowa, M. Kornecki, H. Małkiewiczówna (red.), Gotyckie malarstwo ścienne w Polsce, Poznań.

Kępiński Z. 1946, Odkrycie w Strzelnie, „Biuletyn Historii Sztuki i Kultury”, R.VIII, Nr 3/4, Warszawa, s. 202-207.

Kępiński Z., Józefowiczówna K. 1952, Grobowiec Mieszka Pierwszego i najstarsze budowle poznańskiego grodu, „Przegląd Zachodni”, R. 8, T. II, nr 5-8, s. 370-397.

- 1953, Strzelno, w: A. Gieysztor, Kierownictwo badań nad początkami państwa polskiego, „Przegląd Zachodni", R. 9, T. I, nr 1-5, s. 229-230.

Kiepuszewska M. 2003, Dokumentacja konserwatorska prac przy polichromii ściennej $w$ apsydzie prezbiterium kościoła pw. Świętej Trójcy w Strzelnie, Bydgoszcz, ss. 20 (maszynopis w delegaturze Wojewódzkiego Konserwatora Zabytków w Toruniu, Bydgoszcz, ul. Jagiellońska 1).

Kóčka-Krenz H. 2003, Badania nad architektura przedromańska na poznańskim grodzie, „Archaeologia Historica Polona", T. 13, Toruń, s. 73-84.

Korpała M. 2014, O potrzebie nowego katalogu malowideł gotyckich $w$ Polsce. Kilka uwag na marginesie wybranych odkryć ostatnich lat, w: T. Janiak, D. Stryniak (red.), Średniowieczna architektura sakralna w Polsce $w$ świetle najnowszych badań, Gniezno, s. 413-423.

Kurnatowska Z. 2009, Opactwo romańskie w Lubiniu. Wyniki szczegółowej analizy informacji z badań wykopaliskowych i odkrywek architektonicznych, w: T. Janiak (red.), Architektura romańska w Polsce. Nowe odkrycia i interpretacje, Gniezno, s. 223-250.

Małachowicz E. 2009, Dwie romańskie katedry we Wrocławiu, w: T. Janiak (red.), Architektura romańska $w$ Polsce. Nowe odkrycia i interpretacje, Gniezno, s. 95-106.

Mroczko T. 1972, Czerwińsk romański, Warszawa.

Musiałowski A. 1990, Monety z badań archeologiczno-architektonicznych $w$ Strzelnie $w$ świetle obiegu monetarnego na Kujawach w XIV-XVIII w., w: J. Chudziakowa (red.), Z badań nad średniowieczna architektura Kujaw i Wielkopolski Wschodniej, BMiOZ seria B, t. 86, s. 99-108.

Orłowska E. 2003, Badania chemiczne pigmentów $i$ spoiw polichromii ściennej $w$ apsydzie prezbiterium kościoła pw. Świętej Trójcy w Strzelnie, Bydgoszcz, ss. 9 (maszynopis w delegaturze Wojewódzkiego Konserwatora Zabytków w Toruniu, Bydgoszcz, ul. Jagiellońska 1).

Pastoureau M. 2006, Średniowieczna gra symboli, Warszawa.

Paszkiewicz B. 2013, Moneta w dawnym Gdańsku. Badania archeologiczne w latach 1997-2009, w: H. Paner (red.), Archeologia Gdańska, tom IV, Muzeum Archeologiczne w Gdańsku, Gdańsk.

Poksińska M. 1993, Polichromia romańskiej $i$ wczesnogotyckiej rzeźby architektonicznej. Zespół rzeźby trzebnickiej, UMK - Rozprawy, Torun.

Pietrusińska M. 1971, Katalog i bibliografia zabytków, w: M. Walicki (red.), Sztuka polska przedromańska i romańska $w$ Polsce do schyłku XIII wieku, vol. 2, Warszawa. 
Rodzińska-Chorąży T., Włodarek A. 2009, Uwagi na temat nowych odkryć w kościele pw. św. Andrzeja $w$ Krakowie, w: T. Janiak (red.), Architektura romańska w Polsce. Nowe odkrycia i interpretacje, Gniezno, s. 279-294.

Rzepińska M. 1989, Historia koloru w dziejach malarstwa europejskiego, t. 1, Warszawa.

Sawicki T. 2004, Zagadnienie pozostałości architektury przedromańskiej w pólnocnej części góry Lecha (gród ksiażęcy) w Gnieźnie, w: T. Janiak, D. Stryniak (red.), Początki architektury monumentalnej w Polsce, Gniezno, s. 143-156.

Sikorski Cz. 1994, Historia budowlana strzeleńskich kościołów, w: R.L. Andrzejewski (red.), Z dziejów Strzelna, Gniezno, s. 29-46.

Sienkiewicz M. 2017, Światto - Szkło - Witraż, w: S. Siemianowska, P. Rzeźnik, K. Chrzan (red.), Ceramika i szkło $w$ archeologii i konserwacji, Wrocław, s. 419-432.

Soćko A. 2008, Romański klasztor norbertanek w Strzelnie na Kujawach- problemy, zagadki, interpretacje, w: T. Sawicki (red.) Studia nad dawna Polska, t. 1, Muzeum Początków Państwa Polskiego w Gnieźnie, s. 91-110.

- 2009, Romańskie detale kamieniarskie kompleksu w Strzelnie w Muzeum Narodowym w Poznaniu. Uwagi na marginesie prac nad katalogiem zbiorów Galerii Sztuki Średniowiecznej, w: A. Badach, M. Janiszewska, M. Tarkowska (red.), Visibilia et invisibilia w sztuce średniowiecza. Księga poświęcona pamięci profesor Kingi Szczepkowskiej-Naliwajek, Warszawa, s. 33-48.

Sroka Z. 2000, Romańskie kolumny figuralne w Strzelnie (Ikonografia), Gniezno.

Sulkowska-Tuszyńska K. 1997, Średniowieczne naczynia ceramiczne z klasztoru norbertanek w Strzelnie, red. M. Tuszyński, Toruń.

- 2002, Oltarz główny kościoła klasztornego w Strzelnie - zamurowana historia, „Materiały do Dziejów Kultury i Sztuki Bydgoszczy i Regionu", Bydgoszcz, s. 152-158.

- 2006, Klasztor Norbertanek w Strzelnie (XII-XVI wiek). Sacrum i profanum, UMK Toruń.

- 2009, Bazylika Św. Trójcy w Strzelnie - niektóre odkrycia w latach 2000-2004, w: T. Janiak (red.), Architektura romańska w Polsce. Nowe odkrycia i interpretacje, MPPP w Gnieźnie, Gniezno, s. 455-466.

- 2010, Rzecz o życiu i śmierci na wzgórzu klasztornym w Strzelnie, w: A. Radzimiński, D. Karczewski, Z. Zyglewski (red.), Sanctimoniales Zakony żeńskie w Polsce i Europie Środkowej (do przełomu XVIII i XIX wieku), Bydgoszcz-Torun, s. 412-424 + CD-R.

Świechowski Z. 1963, Budownictwo romańskie w Polsce Katalog zabytków, w: A. Wolff (red.), Źródta do historii kultury materialnej, IHKM PAN Wrocław-Warszawa-Kraków.

- 1972, Strzelno romańskie, w: Cz. Skowroński (red.), Strzelno romańskie, Strzelno, s. 5-24.

- 2000, Architektura romańska w Polsce, Warszawa.

- 2009, Katalog architektury romańskiej w Polsce, Warszawa.

- 2014, Rola koloru w architekturze romańskiej na wybranych przyktadach francuskich, w: T. Janiak, D. Stryniak (red.), Średniowieczna architektura sakralna w Polsce w świetle najnowszych badan, Gniezno, s. 205-214.

Walicki M. 1932-33, Budowle Strzelna na tle sztuki romańskiej w Polsce, „Biuletyn Historii Sztuki i Kultury" I, s. 20-30.

Walicki Z. 1971, Dekoracja architektury i jej wystrój artystyczny, w: M. Walicki (red.), Sztuka polska przedromańska i romańska w Polsce do schytku XIII wieku, cz. IV, Warszawa, s. 197-248.

Wyrwa A.M. 2004, Monumentalna i drewniana architektura sakralna $w$ tekneńskim kompleksie osadniczym do końca XIII wieku, w: T. Janiak, D. Stryniak (red.), Początki architektury monumentalnej w Polsce, Gniezno, s. 213-244.

Zimnowoda-Krajewska B., Salm J. 1992, Problematyka badań architektonicznych ponorbertańskiego kościoła p. w. Św. Trójcy w Strzelnie, „Acta Universitatis Nicolai Copernici”, Archeologia 20, Archeologia Architektury 2, UMK Toruń, s. 21-48.

Żurowski K. 2002, Gniezno - stołeczny gród pierwszych Piastów w świetle źródeł archeologicznych, w: K. Tymieniecki, G. Labuda, H. Łowmiański (red.), Początki państwa polskiego: księga tysiaclecia, PTPN - Wznowienia, Poznań, s. 61-90. 